\title{
Primera parte:
}

\section{François Dagognet, Cuestiones prohibidas \\ París: Les Empêcheurs de penser en rond/Seuil, 2002}

\author{
Traducido por Luis Alfonso Paláu C. \\ Medellín, julio de 2008-mayo de 2009. \\ DOI: $10.22395 /$ csye.v6n12a9
}

\section{Prefacio}

\section{A la búsqueda de un fundamento moral}

Nadie puede dudar de la importancia de las decisiones políticas actuales como la semana laboral de 35 horas, la creación de empleo con miras a reabsorber el desempleo, la desconcentración administrativa, la ayuda a los más débiles, la igualdad hombre/mujer en la representación. Pero, subyacente a estas medidas que caracterizan nuestra época y la modernizan, se levanta otro mundo mucho más fundamental.

Lo decisivo - que voy a tomar en cuenta- ya no concierne lo tocante al funcionamiento de la ciudad, sino a sus bases y a sus valores, a lo que trastorna la existencia: la familia, el cuerpo mismo, del nacimiento a la muerte (la adopción, la esterilidad de las parejas, la extracción de órganos de un moribundo, etc.). Me propongo pues examinar cómo los progresos de la biología y de la medicina nos conducen a prever otras maneras de vivir; me gustaría encarar los avances del bio-poder y de la nueva moral, tomada en el sentido de una ciencia de las costumbres y de los comportamientos.

El lector no me seguirá fácilmente; quizá se opondrá incluso a mis análisis, por dos razones al menos: abordo cuestiones relativamente recientes y que dejan sentir aún el azufre, entre ellos: el aborto, la sexualidad, la guerra a la homofobia, la eutanasia. Y hay otra razón: los problemas aquí planteados suponen muchas perspectivas que se encabalgan, y que por lo demás se me ocurrirá convocarlas a todas, lo que puede dificultar la comprehensión. En efecto, el jurista tanto como el político o el moralista, o, incluso, el teólogo participarán en el debate. Conviene, sin embargo, distinguir claramente su papel: la ley contiene lo que de ahora en adelante está asegurado y exigido; el político -que ha votado para aprobar los reglamentos- se preocupa por los que vendrán a completar o a corregir los antiguos. El jurista trabaja para definir mejor y para precisar lo que el político ha decidido en sus líneas principales. Pero el moralista va más lejos: piensa en lo que convendría en sí; no se pliega a la opinión, rechaza las componendas y los 
compromisos a los cuales está obligada a ceder la mayor parte de los gestores administrativos. Se atiene al rigor de los principios que el político abandona desde que teme la reprobación de los electores que representa. El moralista se separa también del teólogo porque este último se inspira en un dogma que no todos aceptan, mientras que él mismo encara lo racional, dicho de otra manera: los principios.

No dejaré de recordar que lo esencial es referirse a un fundamento del que se derive todo lo demás; la doctrina y sus conclusiones solo valdrán si se respeta este método: descubrir y validar un principio gracias al cual podamos zanjar y deducir consecuencias. Esto excluye sobre todo el caso por caso, las respuestas variables, por no decir discordantes.

Tomaré el camino del moralista que, precisamente, no puede dejar de irritar en la medida en que defiende posiciones que corren el riesgo de valer solo en un porvenir aún lejano; el moralista se desprende del presente, al que todos permanecen sujetos, bajo el pretexto de jugar al realista y al complaciente.

\section{¿Cuál moral, ayer?}

Me preocuparé pues principalmente de dos disciplinas maestras, la biomedicina y la moral. Son inseparables porque la moral no puede dejar de acompañar, hoy más que ayer, al biomédico, sea que sostenga, sea que discuta sus proezas. Estas dos disciplinas solo han tenido en el pasado relaciones bastante pobres, traducidas en un Código de deontología, que esencialmente enunciaba los deberes, algunas reglas a las cuales estaba sometido el que entraba a la cofradía y que, por lo demás, prestaba el juramento de Hipócrates.

Voy a recordar algunas de esas obligaciones con el fin de mostrar hasta qué punto los lazos entre el médico y la moral contaban poco, y también con el fin de notar que el Código, a pesar de su delgado contenido, va a sufrir el contragolpe de la revolución en curso, que sacude toda la biomedicina. Creo útil entregarme a un preámbulo histórico que evidenciará hasta qué punto son recientes las cuestiones que vamos a tratar; ayer, nos contentábamos con darle algunos consejos al futuro médico general. Mejor aún, esta referencia al Código se justifica, pues él contiene lo que es demolido por la biomedicina contemporánea en plena efervescencia; representa pues no tanto el pasado como lo que está rebasado.

Uno de estos preceptos le enseñaba al médico general la importancia de la responsabilidad, y también cómo podía escapar a acusaciones. ¿De qué manera? Al comienzo el médico debe ser vigilante si quiere evitar la inculpación. Deberá soportar la sanción -la de la reparación- si se muestra negligente (inexcusable si, por ejemplo, olvida una compresa en el abdomen de su paciente) o actuando con 
ligereza (se ha privado, en el curso de una operación, de una ayuda considerada necesaria) o descuidado (un "enyesado", después de una fractura, se queja de dolor, pero el cirujano no se detiene; entonces se instala la gangrena y vendrá la amputación; habría sido necesario escuchar al enfermo). Pero, en general, el médico tratante se sale de sus dificultades porque él solo está sometido a la obligación de los medios, y de ninguna manera a la de los resultados. El error pesa relativamente poco, pues solo se persigue realmente la falta o la negligencia, y no la torpeza.

Tomemos el ejemplo del niño trisómico que nace en una familia (regresaré sobre este litigio). Sus padres habían solicitado una punción del líquido amniótico, o amniocentesis, susceptible de revelar una anomalía grave. El laboratorio encargado del análisis cromosómico concluyó en un cariotipo normal. Fue demandado pero él se escudó -y el tribunal le dio la razón- en la existencia de un margen de error incompresible (1 en 100.000 exámenes en la época del proceso). Los padres fueron pues denegados en su demanda.

No perdamos hoy de vista que el médico corre más riesgos que ayer. Las terapias actuales sorprenden por su eficacia; si el médico no recurre a su poder, falta a su deber, pero, si prescribe el medicamento ad hoc en una dosis demasiado elevada, comete una falta pues las armas farmacológicas deben ser manejadas con precaución; incluso ocurre que una posología demasiado débil sea la causa de un drama. El terapeuta debe mostrarse vigilante a todo lo largo del tratamiento. Cuando su arsenal solo comprendía remedios anodinos (extractos de plantas), se encontraba al abrigo.

De modo más general, notemos que la moral de ayer, que escoltaba la medicina, glorificaba la naturaleza. Era claramente esta última la que fijaba tanto la hora del nacimiento como la de la muerte. Había que plegarse a aquello que no se sabía modificar; no se abandonaba verdaderamente la tradición hipocrática que para sanar apelaba a los aires y a las aguas, así como a los simples ejercicios corporales.

Igualmente, en el período que precede a la revolución que me propongo comentar, un tribunal no ha dudado en procesar civilmente a un cirujano que había operado a un enfermo de una importante malformación de las piernas, una hipertrofia elefantiásica; la operación, seguida de gangrena, necesitó una amputación. La intervención, a la vez curativa y reparadora, fue conducida sin cometer la menor falta. Pero el tribunal le dio vuelta al argumento y concluyó precisamente en el carácter particularmente peligroso de este tratamiento; bien llevado, y solo condujo a un fracaso. Esta cirugía con connotación estética iba demasiado lejos y no tenía nada de indispensable. Lo que rebasa el cuadro o las líneas de la corporeidad es entonces condenado y entraña una indemnización. 
Un historiador de la medicina comenta así esta decisión: "Para los teólogos, y santo Tomás en particular, toda mutilación está prohibida porque es conforme a la naturaleza que el cuerpo humano posea todos sus miembros, y es contrario a la naturaleza que sea privado de uno de ellos. Solo podría convertir en lícita esta mutilación la necesidad de salvaguardar el cuerpo entero de una contaminación fatal. Pues se trata entonces de conservar la vida... No podemos dejar de pensar que los jueces se han inspirado en estas consideraciones" ${ }^{1}$.

\section{El cambio deontológico actual}

Actualmente vivimos y juzgamos en lo inverso; nos hemos emancipado de nuestra sumisión a la naturaleza; suprimimos el embrión y recortamos la agonía; ya no dudamos en intervenir en las dos extremidades de la existencia. Es verdad que bajo ciertas condiciones. De acá se deriva que medicina y moral se aproximan, en la medida en que la medicina comanda acciones hasta entonces no-encarables. Por ejemplo, el obstetra puede de aquí en adelante preconizar el aborto de un feto mal formado. Esta posibilidad reciente le es ofrecida gracias a la ecografía que, antes de la venida al mundo, provee la imagen del que está afectado de una grave deformación morfológica.

Correlativamente, la responsabilidad del médico se transforma en nuestra presencia. El derecho no se limita ya, como ayer, a proteger al discípulo de Esculapio, incluso si él puede cometer errores debido a la complejidad de sus aparatos, y del atrevimiento de sus intervenciones. Llega a preocuparse de la víctima. Estas víctimas se organizan, se reagrupan para exigir justa contrapartida; lo que es totalmente nuevo es que la ausencia de falta no es suficiente ya para liberarse de la obligación de reparar. Todo daño, cualquiera sea, exige lo que lo aliviará y ofrecerá una compensación. El hospital está obligado a indemnizar los enfermos de la fiebre nosocomial (llamada a menudo tifo del hospital), aunque no se encuentre el menor abandono en los cuidados ni ningún déficit en las instalaciones. De aquí en adelante es suficiente con que un tratamiento se desenvuelva mal e intoxique al paciente para que el médico o el laboratorio deban responder por ello. Por esto mismo, los que brindan cuidados se aseguran de ahora en adelante contra todos los nuevos peligros que los asechan.

Recordemos por ejemplo la sentencia del Consejo de Estado del 9 de abril de 1993 (sentencia llamada Bianchi). El Consejo de Estado debe arbitrar aquí una querella de retaguardia. Después de una arteriografía -un examen en principio sin sorpresas- un enfermo queda paralizado (una cuadriplejia). Nada dejaba preverlo y todo se desarrolló según las reglas; sin embargo, el hospital

\footnotetext{
1 É. Arrighi de Casdanova, La Responsabilité médicale et le droit común de la responsabilité civile. Ed. provençales, 1946, p. 64.
} 
fue duramente condenado a la indemnización. El Consejo -al mismo tiemporeduce el alcance de su juicio: importa -y esta será la primera condición para la reparación- que el enfermo no estuviera predispuesto al riesgo que lo golpea; o, además, que el acto incriminado haya sido decidido con entero conocimiento (su carácter indispensable al diagnóstico debe ser reconocido); en fin, el accidente debe estar en relación directa con el examen.

El asunto de la sangre contaminada iba también en este sentido: una ley fue votada el 31 de diciembre de 1991 con el fin de que las víctimas de la transfusión sean indemnizadas, cualquiera sea la fecha de la contaminación.

Según los adversarios de esta orientación jurídica, actualmente en vigor, la medicina saldría debilitada de estas sentencias. Esto podría llevarla a renunciar en el porvenir a técnicas arriesgadas, aunque esenciales. Por otra parte, ¿cómo podría defenderse contra lo imprevisible (los riesgos terapéuticos, entre otros), o contra un prion, un agente contagioso que no se sabe aún ni desalojar ni vencer? Ahora bien, ¿no es inconcebible que se esté obligado a reparar aquello contra lo cual no se puede nada?

En el punto de vista opuesto, yo pienso que esta nueva orientación jurídica favorece el desarrollo de la biomedicina; ante todo le obliga al médico tratante, y, sobre todo, al hospital (amenazado por el número y la burocracia), a poner más atención aún. En cuanto al argumento según el cual no se debería sancionar, civilmente hablando, a aquel al que nada se le puede reprochar (incluso él actuó de la mejor manera, por el bien del enfermo), no puede ser aprobado. Es evidente que el hospital, más responsable que nunca, aprenderá a evitar así lo que soporta momentáneamente; en efecto, sabremos pronto cómo y por qué una arteriografía puede terminar en una parálisis. La investigación gana preocupándose por la situación que he recordado. No existe incendio sin causa y, cuando se descubre su razón de ser, hay que evitarla.

El acto biomédico se rodea de ahora en delante de una atmósfera jurídica y moral que lo legitima o lo obliga a soportar las consecuencias de un tratamiento defectuoso, para no llamarlo ilícito.

\section{Evitar el moralismo}

Sin embargo, yo condenaría a un cirujano inglés no por lo que él hizo sino, por el contrario, por su negativa a tratar. No quiso practicar un injerto a un joven paciente bajo pretexto de que este último no había aceptado la posibilidad de una extracción de sus propios órganos en caso que entrara él mismo en un coma profundo. ¿Por qué concederle a alguien lo que él mismo no le da a los otros? En esta óptica, el injerto pierde su base de generosidad, puesto que se 
precisa pagarlo de cierta manera con el fin de merecerlo. No se trata de pagar en especies, pero se le exige una especie de equivalente. Ahora bien, la terapia no podría estar sometida a asuntos previos o a condiciones. La verdadera moral excluye al donante-donante que ya tiene que ver con el trueque.

La moral de la biomedicina debe evitar el moralismo, como en el caso en que un cirujano no opera a un pulmonar (un paciente con cáncer de bronquios) porque este no se comprometió a no volver a fumar cuando se sabe que el humo es cancerígeno. También aquí se exige un compromiso sin el cual se le niega el acceso al cuidado.

Pero dejemos estos casos. Como filósofo debo examinar, ya no el viejo problema de la responsabilidad -un problema que se ha transformado de arriba abajo- sino solamente lo que, relativo a esta noción, concierne a la medicina: ¿qué será necesario imputarle?

La biomedicina transforma la sociedad en sus bases, renueva sus valores y su moral. Pero esta moral controla también esta disciplina en plena expansión. El problema de la salud reúne más fuerte que nunca la moral y la medicina, pero también la sociedad y la política, arrastradas a su vez en su surco.

\section{Privilegiar lo cultural}

No he cambiado mis conclusiones; sin embargo, las he expuesto en el pasado, quizá de manera excesivamente elíptica, tal vez abrupta. Eso me ha valido incluso ácidos reproches.

Una proposición -la "nacionalización de los cuerpos"-provocó un alzamiento de broqueles. La mantengo. Y esta es la razón: en un hospital del este de Francia, un infortunado no va a tardar en morir por falta de donación de órganos; no se dispone de un corazón para transplantarlo. En la noche, un muchacho (un menor) víctima de un accidente de tránsito y en coma profundo entra en las urgencias del mismo hospital. La compatibilidad histológica entre el donador y el receptor se revela positiva, pero los padres se niegan a la extracción.

¿Quién no se entristece con este drama? Hubiera preferido que un colegio de médicos, o incluso de expertos, que representara lo racional, pudiera oponerse a las preferencias individuales (por muy comprensibles que sean) e imponer la solución salvadora. La Ley del 29 de julio de 1994 previó claramente un Comité, pero solo se pronuncia sobre el respeto de los principios y reglas relativas a la extracción, sea en una persona viva, sea en una persona fallecida. La ley mencionó también -y afortunadamente- que "los médicos que procedieron a retirar un órgano en un fallecido están obligados a asegurar la restauración decente de su cuerpo" (art. L. 671-II). 
Mis adversarios, a pesar de sus afirmaciones, permanecen sujetos a lo biológico que consagran e, incluso, sacralizan. En estas condiciones, optan por una perspectiva reductora que llamaremos naturalismo, a veces incluso por un biomaterialismo. He tomado una dirección diferente, por no decir opuesta. Calificaría a este camino de cultural.

\section{Capítulo II}

\section{La asistencia médica a la procreación, o cómo la moral y la biología hacen buena pareja}

Acabo de examinar los problemas ligados al aborto ${ }^{2}$, ya sea voluntario o médico. Regreso a mi proyecto, y por tanto al plan anunciado: encarar la vida, luego su creación -la procreación- hasta su fin (la eventual eutanasia), puesto que la medicina del siglo XX transformó esos momentos decisivos. Me interrogaré sobre la eventual justificación de lo que es o será propuesto, técnicamente hablando. ¿Hasta dónde conviene ir, o entonces: por qué tal o cual restricción? Ayer, lo único que podíamos hacer era padecer, mientras que hoy podemos siempre mejor modificar o suspender lo tocante a nuestra propia existencia. Ya he mostrado que el aborto terapéutico se ha hecho esencialmente posible, o al menos facilitado, por los progresos de la imagenología médica que alerta sobre una eventual malformación.

Abramos ahora el examen de los problemas ligados ya no a la cesación eventual de la entrada en la vida (el aborto) sino a la llegada del niño y a lo que la facilita: la asistencia médica a la procreación (AMP).

\section{Victoria sobre la esterilidad}

Nada es más entristecedor que la esterilidad, vivida, por lo demás, no solamente como una privación sino también como un deshonor, el efecto de una disminución, para no mencionar incluso la enfermedad (confundida con la impotencia). Una comunidad que se compone de "dos" le falta seguramente su perpetuación; a causa de su restricción y de sus incapacidades, parece consagrada a la descalificación. También la medicina interviene y trata de corregir una tal deficiencia.

Me atendré a las situaciones más simples. Primer tiempo de mi examen: el marido sufre de una oligospermia (una simiente escasa) o de una astenospermia (una insuficiencia en la movilidad espermática), en suma: de una carencia cuantitativa o cualitativa de la producción seminal evidenciada por los exámenes. En cuanto a la mujer, se trata frecuentemente de una obstrucción de las trompas de Falopio (allí donde se unen precisamente los gametos, el óvulo y el

\footnotetext{
2 La reflexión sobre el problema del aborto fue publicada en la revista: Ciencias Sociales y Educación vol. 4, N. 7, pp. 293-308. Nota de editor.
} 
espermatozoide) que impide la fecundación. A veces, incluso, esta mujer fabrica anticuerpos que atacan lo que proviene de su marido.

Por regla general, la medicina de la reproducción propone, entonces, la inseminación directa con el esperma del marido, o inseminación con esperma del cónyugue (IAC). Todos se imaginan sin dificultad la modalidad: la introducción del esperma marital en el útero con la ayuda de una pipeta, por medio de un gesto aparentemente simple. O bien se trata de evitar el obstáculo que impedía la fusión gamética -aunque el útero pueda no aceptar la inyección y que la mucosa esponjosa no se prepare para el anidamiento del ovocito fecundado- o bien, el médico busca concentrar "el licor seminal" demasiado diluido.

Otra modalidad bastante próxima, aunque más radical, puesto que la técnica precedente ha podido fracasar, se busca la fusión directa del óvulo y del espermatozoide en un tubo de ensayo (in vitro); después de dos días, el médico se asegura del resultado y le confía a la madre el cuidado de proseguir lo que ya había comenzado. Es la Fecundación in vitro y transferencia de embrión (Fivete).

Esta técnica atrae mi atención muy particularmente; por una parte, con ella todo ocurre afuera (al menos la fecundación y sus primeras fases); se han evitado los obstáculos internos, así como las complicaciones del adentro. Por otra parte, la sexualidad y la fecundación son separadas aquí, lo que enerva e irrita al crítico. El nacimiento de un individuo, su origen, sus primeros desarrollos se operan en ausencia de sus genitores o, más bien, por fuera de las relaciones humanizadas, como si asistiésemos a una manipulación material sustitutiva. El marido ha sido transformado en un simple proveedor. En cuanto a su mujer, ella se limita a recibir. El tubo de ensayo ha servido de mediador, lo que permite -por algún lado y sobre todo a los ojos de los adversarios- desacralizar y deshumanizar la procreación.

Yo considero estas técnicas como una victoria; deberemos aprobarlas moral y filosóficamente - sin reservas- y no compartir ninguna de las consideraciones que a menudo las rebajan. Ya (lo que debería moderar la crítica) el ginecólogo no ha solicitado nada que no venga de los cuerpos de los esposos. Se ha inspirado, de un extremo al otro de la terapia, en el acto sexual al que ha imitado. Se ha dedicado a sacarle el cuerpo a los obstáculos que entraban la fusión celular.

La Ley 94-654 de julio 29 de 1994, relativa (entre otras) a la asistencia médica a la procreación y al diagnóstico prenatal, fijó las condiciones a la IAC: "El hombre y la mujer que forman la pareja deben estar vivos, en edad de procrear, casados o en la medida de aportar la prueba de que llevan una vida en común de al menos dos años y que consienten previamente (...) la inseminación" (artículo L. 152-2).

Lo que parece simple y que se inspira tan claramente en los procesos naturales de la fecundación se encuentra, sin embargo, con complicaciones - 196 
médicas, y sobre todo morales, de las que los adversarios de la asistencia médica a la procreación (AMP) van a echar mano para condenarla. No me asociaré a su reprobación, pero reconozco que -allí donde todo parecía evidente y donde cualquiera creía apercibir una medicina elemental de la esterilidad- esta terapia se revela una fuente de conflictos, y a veces, de interrogaciones.

Por ejemplo, de parte mía solo suscribo parcialmente la exclusión de la soltera del beneficio de la inseminación con donante (IAD), aunque haya casos en los que el rechazo se justifica (como cuando se trata de una joven que rechaza toda relación sexual pero desea un niño, pues esta motivación es eminentemente patológica). Pero ¿no existen otras solicitudes que pudieran ser acogidas? No oculto mi perplejidad, a tal punto la ley se forjó en el molde de la familia tradicional (la obligación trinitaria). Más vale asegurarle un hijo a una pareja que lo desea, pero ¿es esta una razón para rechazar lo menos sólido?

Como es preciso no caer en la indecisión en moral, menos que en otras partes, no podemos facilitar una tal posibilidad. No se la concedemos pues a la soltera, a pesar de una ligera duda y de un sentimiento que pesa sobre tal evicción. Por lo demás recordaría que el legislador, a veces desconcertador, autoriza la adopción de un niño por parte de una mujer sola. iEsto no concuerda fácilmente con aquello!

Todavía aquí, se impone una concepción un tanto más sofisticada: en un caso -la adopción- el niño ya estaba ahí presente y se le busca un sostén; pero con la otra situación -la inseminación- se contribuye a poner en el mundo al que le faltará al menos uno de sus padres, y que verosímilmente sufrirá por ese desequilibrio. iNo confundamos las dos operaciones! Los partidarios del naturalismo biológico (con los que no estoy de acuerdo ni aquí ni en ninguna parte) deberían darle ventaja a la maternidad de la soltera, pues el niño nacido de ella no estaría privado de una filiación biológica.

Pero no estoy convencido de una tal explicación. Tenemos pues que el Estado mantiene dos hierros en el fuego: le rechaza a la soltera lo que le ofrece por el otro lado.

\section{Objeciones a la fecundación artificial}

Regresemos a la Fivete (Fecundación in vitro y transferencia de embrión), que combate la esterilidad, una esterilidad que, por lo demás, parece extenderse. Estemos prestos a escuchar las dos graves críticas que se levantan contra ella, y que me dedicaré a desmontar.

Ante todo, la primera refutación de parte de sus adversarios: con el fin de realizar la Fivete, importa apoderarse de las células germinales u ovocitos antes de fertilizarlos en el tubo de ensayo. Para hacerlo, el terapeuta provoca 
una hiperestimulación ovárica; luego punciona y recoge los ovocitos bajo anestesia general. Puede también, gracias a los progresos de la ecografía que le guía, buscar alcanzar estas células por la vía vaginal. Ahora bien, los riesgos ligados a esta prueba conducen al médico a una extracción que no se limita a obtener un solo ovocito. En caso contrario, fracasaría. La débil tasa de éxito en la implantación in utero le empuja pues a contar con ovocitos de recambio. Por esto, la producción de embriones llamados excedentarios o supernumerarios. El médico procede así con tanta más determinación y seguridad cuanto que la tecnología permite el congelamiento, y por tanto, la sobrevivencia, de esos embriones.

Por otra parte, en caso de éxito en la implantación-anidamiento de algunos de ellos, es probable que ocurra un embarazo múltiple. Con el fin de favorecer el desarrollo de uno o de muchos embriones (dos o tres), será necesario entonces proceder a una "reducción embrionaria" por punción transabdominal; guiándose radiológicamente se alcanza la cavidad cardíaca de los embriones a los que se destruye con una inyección.

El biólogo terapeuta ¿no transgrede en dos ocasiones abiertamente la ley al mismo tiempo que viola los principios fundamentales de la moralidad? ¿No se comporta como un bárbaro? El aborto solo está autorizado en las doce primeras semanas del embarazo. Ahora bien, la destrucción inevitable de los embriones supernumerarios, como la reducción del número de los que serán implantados, se opera más allá de este plazo, y sin que se pueda afirmar que este embarazo múltiple ponga gravemente en peligro la salud de la madre, o defina una situación de angustia.

En su aviso 244, el Comité consultivo <francés> de ética ha subrayado claramente que el ginecólogo había rebasado el cuadro de la ley y que estaba en plena ilegalidad. Esta destrucción fetal no ha sido abordada o sancionada en la Ley del 29 de julio de 1994 que trata, sin embargo, de todo lo tocante a la procreación. Y con fundamento, embrolla. En desquite, en el tema de los embriones supernumerarios, la ley admite en última instancia que "si su acogida es imposible, y si la duración de su conservación es al menos igual a cinco años, se le puede poner fin a esta conservación" (cap. II bis, art. 9). Sin embargo, no deja de recomendar con insistencia que sean primero cuidadosamente conservados y ofrecidos a parejas solicitantes.

Y acá tenemos el problema: si el aborto está implicado hasta este punto en la Fivete -y es condenable puesto que no respeta ninguna de las condiciones que lo harían aceptable-, ella debería ser impedida en razón de lo que supone. Y, sin embargo, vamos a legitimarla. 
Por una parte, la reducción embrionaria está únicamente destinada a favorecer la sobrevivencia de los embriones (dos o tres solamente) que podrán así llegar a término de su desarrollo uterino. Al tratar de preservarlos a todos, ninguno lograría su acabamiento. En suma, la muerte de los unos condiciona la sobrevivencia de algunos otros. En cuanto a los embriones excedentarios congelados, es claro que el don debe imponerse y que así escaparán a la supresión pura y simple. Es necesario felicitarse porque el embrión no es ni una cosa (un montón celular) ni una persona potencial sino una persona que puede prevalerse de derechos fundamentales, especialmente el de existir.

El legislador autoriza plenamente esta medicina. No es este forzosamente un argumento suficiente a su favor, pues lo lícito no siempre equivale a lo moral.

\section{El diagnóstico de las perturbaciones hereditarias}

Por lo demás, otra vez, el Estado desaprueba -y por tanto limita-singularmente el diagnóstico prenatal, pero, al mismo tiempo, lo anima puesto que la Caja Nacional de Seguridad contra la Enfermedad (CNAM) y la Asociación Francesa para el Diagnóstico y la Prevención de las Desventajas del Niño toman a su cargo los exámenes y los reembolsan. De acá se desprende un diagnóstico de las anomalías cromosómicas, así como la revelación de los trastornos metabólicos. Pero, un momento; distingamos: el DPN (el diagnóstico prenatal), practicado en el curso del embarazo gracias a una amniocentesis (punción del líquido amniótico), permite conocer el sexo del embrión y, eventualmente, algunas anomalías graves que conducen a la IME. El DPI (el diagnóstico preimplantatorio), practicado antes de la implantación del embrión salido de una fecundación in vitro, permite-gracias a técnicas comparables- diagnosticar anomalías y por tanto solo transferir los embriones sanos.

En 1988, la Comisión Nacional de Medicina y de Biología de la Reproducción fue creada -en Francia-, con una sección encargada de todo lo que tiene que ver con el diagnóstico prenatal. Un decreto fijó la lista de los laboratorios autorizados, susceptibles de llevar a buen término los análisis tanto genéticos como bioquímicos.

Los adversarios de las tecnologías del AMP olvidan que el diagnóstico prenatal, y el diagnóstico preimplantatorio solo buscan identificar las patologías fetales más severas. Esta medicina predictiva solamente se adelanta al mal, y se impone sobre la que solo se desvive por limitarlo o por retardarlo.

En verdad, el obstetra solo tiende a sustraer el feto de las afecciones más temibles, cuando la alteración genética se revela portadora de efectos ciertos. Se abstiene si prevé trastornos curables o tardíos. La corea de Huntington provee 
un buen ejemplo puesto que, incluso si es incurable, solo se declara pasados los cuarenta años.

No le asignemos al terapeuta (buscando diabolizarlo) un propósito radical y depurador, a tal punto es difícil quitarle a la vida su zona oscura. Y, por lo demás, no se puede leerlo todo a partir del examen realizado en una toma de sangre o sobre la extracción de células fetales.

El diagnóstico prenatal solo sirve para fortificar el IAC -y, por tanto, para ayudar a una familia- permitiéndole asegurar un niño viable.

No hemos cesado de festejar esta IAC que autoriza lo inimaginable, y que debe ser colocado entre las proezas de la biomedicina; alegra a las parejas estériles y les permite también crecer a las familias separadas (del prisionero de larga duración, del viajero a países lejanos, del individuo que debe someterse a un tratamiento radioterapéutico, etc.). Es suficiente con que el hombre haya previamente depositado un poco de su esperma en un Centro de estudio y de conservación del esperma (Cecos) para que pueda así transmitirlo; entonces la comunidad podrá agrandarse, a pesar de lo que la obstaculiza (la separación). El IAC logra oponerse tanto al espacio como al tiempo; en efecto, el congelamiento del esperma permite la suspensión de la fecundación.

\section{El reemplazo del padre}

La inseminación con el esperma de un donante anónimo (IAD), más audaz y más arriesgada, planteará aún más interrogantes. Los natalistas no dejan de explotar esta situación bastante desconcertadora.

La examinaré con el fin de librarla de las observaciones negativas que la oscurecen. Me propondré reintegrarla a la moralidad, de donde se la desaloja.

En este caso, el marido o el concubino sufre de azoospermia: no puede ya fecundar, mientras que en el caso precedente él solo estaba afectado de un debilitamiento o de una insuficiencia espermática, lo que conducía al IAC.

O también, el marido teme -no sin razón-transmitir una enfermedad hereditaria que lo afecta. La esposa no estará encinta más que si el biólogo practica la inseminación con el esperma de un donante anónimo, desconocido de la pareja; sin embargo, será necesario que la pareja dé su consentimiento escrito ante un juez encargado de los asuntos familiares, o ante un notario. El acuerdo prohíbe cualquier impugnación posterior de esta filiación. Por otra parte, ningún vínculo podrá ser instaurado entre el donante y el niño nacido de esta procreación.

En esta perspectiva ino se destruye la familia puesto que un tercero se desliza entre los esposos y asegura la función parental, practicando una especie 
de adulterio institucionalizado? Me opongo inmediatamente a esta interpretación que remite al fundamento estrictamente biológico, al que desde el comienzo he convocado para recusarlo.

La paternidad se define ante todo por la palabra y el papel educativo. Evitemos, por consiguiente, privilegiar lo natural, para reconocer mejor y darle ventajas a la relación afectiva, humana. iNo veamos acá una filiación a medias!

El Cecos, el organismo que detenta y entrega la simiente generadora, la escoge de tal forma que sus efectos logren imitar grosso modo el aspecto del padre educativo, su morfotipo. Conociendo las características físicas del donante, el Cecos vigila el apareamiento de la pareja donante-cónyuge.

Tiene en cuenta también los grupos sanguíneos, no tanto para evitar las incompatibilidades como para ocultarle al niño la identidad del intruso. La similitud buscada está destinada a mantener la ilusión. ¿Es bien necesario favorecer la venida al mundo de un niño con las apariencias (somáticas) relativamente parecidas a las de su padre educativo? ¿No conviene más bien en efecto favorecer no tanto el engaño como la fácil aceptación del uno por el otro? Debería oponerme puesto que yo busco no solicitarle nada a la naturaleza, o lo menos posible, mientras que acá se la imita.

Sin embargo, suscribo esta maniobra porque ella ayuda a no inquietar al niño, le evita interrogaciones y lo desvía de la peligrosa cuestión de los orígenes. Después de todo, el "verdadero" padre no es forzosamente el genitor y, por la apariencia, trato de olvidar al que podría tomar su lugar. Sin embargo, el psiquiatra nos señala que la búsqueda de los "verdaderos" padres no debe ser sub-estimada; la neurosis se alimenta de la mentira que oculta la filiación. Prefiero no tanto resolver este último problema como impedir que se plantee. Dudo que la "verdad verdadera" libere, al ser y permanecer el verdadero y único padre aquel que se ha dedicado a la crianza del niño.

Refirámonos a otras causas limitativas que conciernen esta operación que se hace bajo la égida del Cecos: el donante de esperma debe pertenecer él también a una pareja que ya hubiera procreado y "el recurso a los gametos de un mismo donante no puede deliberadamente conducir al nacimiento de más de cinco niños" (art. L. 673-4). Además, la Ley del 29 de julio de 1994 estipula que "las actividades de recolección, tratamiento, conservación y cesión de gametos no puede ser practicada más que en los organismos y establecimientos de salud pública y privados sin ánimo de lucro, autorizados para este efecto por la autoridad administrativa" (art. L. 673-5). El moralista pensará con menos facilidad que "toda inseminación artificial con esperma fresco proveniente de una donación, y toda mezcla de esperma están prohibidas" (art. L. 673-3). 
Corriendo el riesgo de equivocarme, imagino que las mezclas son susceptibles de arrastrar múltiples complicaciones. Tomemos una: le impedirían a una madre el probar que el niño no nació de un lazo personal sino de la asistencia del Cecos, cuando ocurra que el padre educativo trate de escapar de su obligación y sostenga entonces que su mujer lo engañó. Por su lado, el esperma fresco está descartado pues conviene darle tiempo al Centro para que practique las pruebas que permitan las evaluaciones útiles que permitan detectar, por ejemplo, la presencia de VIH.

Pero ¿qué les reprochan los natalistas a estas técnicas procreadoras de las que sostienen -bien equivocadamente- que sustituyen una sexualidad sin procreación por una procreación sin sexualidad? Ante todo, que en una tal operación, todo reposa sobre una mentira. La verdad de sus orígenes se le oculta al niño. Si termina por ser informado, algunos pretenden que él corre el riesgo de un profundo desequilibrio, que estará desorientado y que oscilará entre dos familias, la pretendidamente natural y una sustituta.

Es por esto que no soy partidario de la revelación del pasado, de la ruptura del anonimato del donante. Se le concede todavía demasiada importancia a lo biológico. Sin embargo, la mayor parte de los teóricos de la IAD lo desean. Según ellos, no se podría engañar con la filiación biológica. La moral que nosotros defendemos, la que exalta "el juego parental", o más bien el querer que llegaría hasta programar "al niño por venir", está aquí indirectamente cuestionada.

Es increíble que algunos psicoanalistas sostengan un tal punto de vista naturalista.

No defiendo, por tanto, la arbitrariedad sin límites; la prueba de ello está en que estoy de acuerdo con la ley que prohíbe la doble donación, la del esperma y la del ovocito, lo que impide "el niño de cuatro padres". El artículo L. 152-3 lo especifica: "un embrión no puede ser concebido con gametos que no provengan de al menos uno de los dos miembros de la pareja". Se exige, incluso, una participación efectiva de uno de los dos padres, así como el acuerdo escrito de aquel del que la técnica asegura su reemplazo. Una perspectiva relacional implica esta adhesión. La evocación del lazo de sangre solo sirve para debilitar el acuerdo del que no ha hecho más que consentir.

Existe otra crítica sobre la cual no me detendré, a tal punto su refutación se cae de su peso: la pareja y el Cecos cómplice arriesgan con buscar un nacimiento a la carta bajo el pretexto de que es menester evitar las incompatibilidades y sacar los dos genomas. $\mathrm{Si}$, por ejemplo, la futura madre sufre ya de dificultades de orden cardio-vascular, descartemos el esperma que contendría riesgos para esta patología que intensificaría. Solo es buscado un feto con buena salud, al abrigo de las taras hereditarias que produciría la duplicación genética incontrolada. 


\section{El reemplazo de la madre}

Pero el IAD, en la mira de los natalistas, encierra un increíble límite que podría o debería descalificarla. En este dominio, me sorprende una cosa extraña: se prevé frecuentemente el reemplazo del marido, pero mucho menos el de la madre. En este último caso -en una inversión de la precedente operación procreativa- un ovocito ajeno, seleccionado, sería fecundado por el esperma del marido.

Sin embargo, será necesario ora solicitar a la esposa que reciba "el embrión fecundado" (cuya mitad del genoma proviene de una donante anónima), ora -si ella no logra la "anidación"- reclutar una mujer que asegurará el embarazo y el parto. Pero si la que ha llevado a término el embarazo decide conservar el niño que acaba de nacer -incluso si ella ya ha recibido los honorarios por el servicio prestado-, ella deberá poderlo hacer, a tal punto son reconocidos los derechos de la madre como única soberana. Un tribunal no podría desaprobar este gesto de apropiación porque el derecho sigue arrimado a lo biológico.

El padre cuenta menos en el acto de procreación. El parto designa el momento determinante, controlable y discriminador; el niño es de la que lo ha dado a luz. Este tipo de operación procreadora corre pues el riesgo de privar a la pareja de lo que esperaba y a lo que se había prestado.

Se le pueden contar al niño del que hablamos, tres madres: la donadora del ovocito, luego la que asegura el desarrollo uterino (la madre portadora), y finalmente la madre educadora y afectiva que será encargada del niño. Se imaginarán el embrollo que puede seguirse de acá. Ya los latinos distinguían mater y genitrix. Nosotros hemos ampliado la disociación.

En lo que concierne a la IAD, no ignoro ni los descontentos ni los conflictos que la acompañan. A pesar de las dificultades de toda naturaleza que la rodean, reconozco en ella una victoria ejemplar. Da a la familia lo que deseaba. La salva, al asegurarle completitud y perpetuación. No solamente ya no se inspira en lo natural, sino que triunfa sobre una biología rebelde, la que se oponía a los "fuegos del amor" y entrababa la procreación.

\section{La oposición del Estado}

Me falta un tercer caso por examinar, que es también el más discutible. Está incluso prohibido por la ley, aunque recientemente se haya flexibilizado; se trata de la inseminación post mortem (IPM). En este caso, el marido no ha sobrevivido ya sea a un tratamiento radioactivo, ya sea, por ejemplo, a su alistamiento en un ejército en guerra. Como el Cecos había previamente recogido el esperma del que se sabía amenazado ¿se autorizará la inseminación de la viuda? 
Pienso que el legislador habría probablemente deseado -mediando algunas restricciones- avalar una tal intervención, pero él metía el dedo en un engranaje. Habría tenido luego que reconocerle esta ventaja a la mujer sola, e incluso a la que nosotros consideramos desequilibrada. El derecho no buscaba descender esta pendiente. Él se resiste a todo lo que nos aleja de lo fisiológico y de lo corporal. Se adhiere a lo que lo lastra o le provee indicios tangibles.

Los opositores a una medicina que trastorna de arriba abajo el nacimiento no dejan de blandir la cuestión del post mortem; ya no se contribuye a preservar la entidad de la familia, nos dedicamos solamente a prolongar la del que ha dejado de existir. El que nacerá será de ahí en adelante un huérfano, un "sin padre", rodeado por una mujer que no habrá probablemente terminado su duelo, y que tratará de reencontrar en su hijo la imagen abolida de su marido, todos datos susceptibles de patologizar la situación. La técnica se desvive aquí para reemplazar a los muertos, o al menos para prescindir de ellos: ellos continúan engendrando. Para los naturalistas, hemos rebasado los límites y entramos en la locura y la desmesura.

No participaré en el escarnio puesto que apruebo la proeza, deseando solamente -con una pequeña restricción- que un cierto tiempo separe el momento de la desaparición del padre y la inseminación, para que tal decisión sea debidamente reflexionada y tomada en frío.

Y ¿por qué acepto lo que la ley no autoriza? Me refiero a mi propio fundamento moral que coloca lo cultural (la voluntad primero) por encima de lo solo biológico. Por el hecho de que la técnica (la esperma que subsiste incambiada después del deceso, porque está crioconservada) permite reunir lo que la muerte ha disociado, se logra vencer el destino; pero, además, no permanezcamos en denominaciones engañosas; tanto aquí el ausente (el muerto) puede presentarse, como el presente se comporta a veces como ausente. Se reconstituye pues lo roto.

¿Por qué rehusar la inseminación post mortem cuando el Código Civil avala el matrimonio entre un muerto y una viviente? Es suficiente con que esta unión sea autorizada por el presidente de la República. La Ley (art. L. 171) data de diciembre de 1959. En diciembre de ese año, se rompió la barrera de Malpasset; entre las víctimas se encontraba un novio que estaba a punto de casarse. La novia, embarazada, obtiene pronto la posibilidad de desposar una sombra, así solo fuera para darle al niño que iba a nacer una filiación legítima; lo natural o lo adulterino en esa época padecía una cierta desigualdad o discriminación. No voy a entrar en la controversia que los juristas han alimentado contra este artículo del Código, tanto más cuanto que este no cede al laxismo: en efecto imenciona que un tal matrimonio no entraña ningún derecho de sucesión en provecho de la esposa sobreviviente! Además precisa que la celebración de 
ese matrimonio solo tendrá lugar si se está seguro del consentimiento del esposo fallecido (en tal caso, el novio había ya cumplido con las formalidades oficiales).

La unión puede también, e incluso de forma más fácil, ser consagrada entre un(a) moribundo(a) (in articulo mortis) y aquella o aquel que se lía con él o ella. Es claro que los casados están dispensados de hacerse presentes en la alcaldía.

Me agrada señalar que una tal singularidad -la agonía terminal impide toda esperanza de conyugalidad, de porvenir, de vida en común, de posteridaddebe su origen a antiguas prácticas religiosas. La extraña ceremonia le sirve al concubino para regularizar su situación, o para ponerse en regla con la Iglesia.

\section{El moralista confirma}

Heme, sin embargo, acá detenido por una dificultad de peso. Al comienzo de mis análisis encontré, o creí encontrar, el fundamento de la moralidad en lo que despliega la personalidad, en lo que exalta el querer o el dominio de un sujeto que escapa finalmente a lo que lo reducía, especialmente lo corporal. Pero, lejos de sostener un programa subjetivista, solicité que toda decisión que se piense liberadora sea sometida a la aprobación del otro, tanto como al poder del legislativo. El Estado representa la voluntad general, la que asegura la solidez de la ciudad. En efecto, nuestros representantes votan no en función de los ciudadanos que los han elegido sino buscando una ley que convenga al conjunto de la nación.

En el dominio de la biomedicina, el sujeto que se libera del peso de la fisiología de la reproducción impone finalmente su escogencia, o su punto de vista. Pero él también debe tener en cuenta la comunidad de base a la que pertenece (la familia, en primer lugar) y lo que permite la sociedad entera, pues esta última vigila la aplicación de reglas que comandan su empuje. En suma, el bien y lo mejor se reconocerán en que sirven tanto al sujeto como a la sociedad que nos engloba, o aún la libertad, pero encuadrada por una legislación.

Pero hace un momento, acabo, sin embargo, de aprobar lo que el derecho prohíbe: preconizo una posible inseminación post mortem (IPM), mientras que la legislación no acepta la inseminación más que con gametos de personas todavía vivientes. ¿No estoy encerrado en una contradicción?

De manera más general, el moralista no dejará de encontrarse en vano con respecto a las recomendaciones y prescripciones sociales, a tal punto estas están marcadas de una pesantez propia de las colectividades. Y para comenzar a salir de la trampa en la cual parezco deslizarme, debo ante todo reconocer la existencia de dos morales: la una consolida los valores tradicionales, la 
otra corresponde a una evolución lenta y sorda. Ella implica el cambio de las mentalidades.

Por ejemplo, en momentos en que la ciudad toleró, e incluso favoreció, la IAC y la IAD, ella debía permitir la IPM que se limita a prolongar la audacia de las precedentes. iNo debe haber aquí dos pesos, dos medidas! Alineo estas técnicas: la IAC cura la insuficiencia del padre, la IAD lo reemplaza por un anónimo, la IPM anula su desaparición.

Aquí, invoco un nuevo criterio que facilita la identificación de la verdadera moralidad: la lógica quiere que lo que vale para un sector dado pueda también valer para los otros, parecidos, ya estén próximos o no. No la universalidad, pero sí la extensión categorial obligada. Domat, en su obra de 1644, Las leyes civiles en su orden natural, exigía:

[...] Una consecuencia de que las leyes sean las reglas del orden universal de la sociedad estriba en que ninguna ley está hecha para servir solamente a una única persona, o en un solo caso, o para un solo hecho particular y singular, sino que ella procura en general a lo que pueda ocurrir, y sus disposiciones tienen que ver con todas las personas y todos los casos donde ellas se extiendan. Es por esto que las voluntades de los príncipes que se limitan a personas particulares y a hechos singulares son gracias, concesiones, privilegios, pero no leyes.

Me niego pues a aislar el IPM, luego, a favor de la separación, para prohibirlo. Por lo demás, el marido ha tomado la precaución de confiar su esperma al Cecos que la ha aceptado; por ello mismo autoriza lo que se sigue. Y ¿cómo no regocijarse de que un muerto no se haya muerto enteramente? Lo viviente en él -la simiente-permite su continuación.

La viuda puede no darle continuación, pero, por su voluntad, ella puede reunirse con la de su marido. Tendré la ocasión de aminorar la fuerza del argumento según el cual yo respaldo la existencia de un niño sin padre educado por su madre sola, ella misma encerrada en el recuerdo, todos elementos que pueden crear un desequilibrio. Con una tal observación, se sigue prisionero de un prejuicio -siempre el incorregible naturalismo- según el cual la mujer está reducida a un papel incambiado, monovalente. Pienso que ella puede, en la urgencia, asumir tanto la función paterna como la función materna. El legislador le ha concedido por lo demás a la soltera la posibilidad de adoptar. Aquí también; lo admitimos i"dos pesos, dos medidas"!

No escuchemos a los filósofos de la familia que solo le reservan a la madre la tarea educativa; no es que se engañen, sino que consideran como un destino lo que solo ha tenido que ver con una lenta evolución, con una repartición de las obligaciones, lo que, por vía de consecuencia, es susceptible de reorientación. Los padres pueden adaptarse a las circunstancias.

- 206 
El filósofo podrá reprocharme que descienda demasiado a los detalles, y todavía he dejado de lado -mientras hacía el camino-numerosas informaciones médicas (todo el campo de la fisiopatología del matrimonio) que repercute sobre las decisiones, a veces incluso las actitudes, algunas veces en los principios mismos.

La moral no se encuentra allí donde algunos la sitúan, en la altura de las ideas o el dominio de la pura reflexión. Sin descanso, la moral se aplica; ella no podría pues abandonar el suelo de la realidad donde se debe inscribir. La dificultad de esta disciplina tiene, por lo demás, que ver con la multitud de los datos a través de los cuales ella debe circular, a tal punto que nadie puede fácilmente trazar una frontera u operar una separación precisa entre dos regiones, porque entre ellas encontramos los intermediarios que las conectan e incluso las fundan. Acabamos de darnos cuenta: incluso el muerto no está verdaderamente muerto. Además del simple hecho de que subsiste en los pensamientos, su simiente -lo viviente de ese viviente- conservado por el Cecos continúa viviendo, y eventualmente transmitiendo la vida.

Todos adivinarán las dificultades de la teoría, si es verdad que esta última está siempre en presencia de casos continuos, aunque debiéramos -cueste lo que cueste- introducir cortes o al menos niveles. Si no, es toda la biomoral la que corre el riesgo de hundirse.

El especialista en bioética no se inquieta verdaderamente con estos problemas. Repite incansablemente que es necesario, y que es suficiente, conectarse a un principio soberano: la defensa de la persona humana que nunca debe ser vista o tratada como un medio (una concepción kantiana). Pero a mí me parece que este fundamento es menos importante que la manera de hacerlo operatorio. Así -para anticipar mi desarrollo-, ¿le contará el médico a su enfermo la gravedad de la afección que lo afecta (la muerte próxima)? ¿O bien le mentirá, a tal punto presiente que no soportaría el choque? ¿Cuál de estas dos actitudes armoniza mejor con el respeto debido al sujeto: la verdad que mata o la mentira que apacigua? Es verdad que el médico se sale de la dificultad por medio de una habilidad: previene al enfermo sobre la gravedad de su estado, pero él se va a consagrar a curarlo (lo verdadero y lo falso cuidadosamente mezclado).

Descartaré también una objeción que se me podría hacer: rechazo desde el comienzo una concepción estrictamente biológica que decidiría en lugar y sitio del hombre. Me opongo al naturalismo cientificista y reductor, aunque él se crea el único defensor de lo humano. Pero esta victoria sobre lo biológico no significa que no lo tenga en cuenta. Lo disminuimos, lo dominamos, lo encuadramos, más bien que someternos a él. Nos lo incorporamos. ¿Cuál es la prueba? La IAC, la IAD, la IPM tan controvertidas -o al menos las dos últimas-no dejan de reproducir el acto generativo, la unión de dos gametos sexualmente diferentes. 


\section{Uno de los límites}

Todo lo que precede explica por qué soy más que reticente en presencia de la medicina siguiente: una mujer de sesenta y dos años se ha beneficiado con la donación de un ovocito (de parte de una donante estadounidense) que ha sido fecundado in vitro con el esperma de su propio hermano. Este último tuvo que disimular su parentesco al Centro americano de procreación. Este mismo esperma sirvió luego para fecundar un óvulo, salido de la misma donadora que estamos mencionando, pero esta decidió asegurar hasta su término la función de madre portadora: entonces nació una niña. Tenemos pues el rompecabezas siguiente: "Dado que mi madre ha llevado el hijo de mi tío, y que este tío es mi padre; y dado además que mi hermana no es la hija de mi madre, ¿qué soy yo misma?". En este caso, a fuerza de desbaratar la naturalidad, se cae en el barullo genealógico, la niebla parental más insoportable. Este prometeísmo llega a afectar las líneas familiares más elementales.

Añadamos aún -en contra de estos desbordamientos-que la biomedicina no cesa de corregir las intervenciones más arriesgadas, o las que son susceptibles de desviación.

Es así como el intra cytoplasmic sperm injection (ICSI), que consistente en inyectar un solo espermatozoide en el corazón del ovocito para vencer la esterilidad, nos saca de una pesada invalidez: le gana en eficacia a la IAC. Exime sobre todo de la IAD puesto que un solo gameto del marido podrá ser suficiente de ahora en adelante. Se evita entonces el recurso a un tercer donante.

\section{Recapitulativo}

Recuerdo los criterios adoptados para constituir una moral de la antiesterilidad:

a. El querer ante todo, o la libertad;

b. Una cierta lógica que obliga a alinear los parecidos los unos sobre otros, para evitar la casuística;

C. El Estado debe zanjar (este último no representa el interés de todos sino, más allá de los intereses, lo que favorece el espíritu de la comunidad);

d. He añadido aquí una dosis de respeto por lo que la naturaleza impone o sugiere, con el fin de evitar las construcciones y operaciones acrobáticas (por ejemplo, no dejaremos de tener en cuenta las diversas generaciones); no podría validar la unión de un ancestro con uno de sus descendientes, realizada bajo pretexto de que la biología conservadora puede inmovilizar las células de la reproducción, prometidas a una casi-inmortalidad. 
La moral, nuestras conductas, saldrán de acá transformadas y renovadas. Es claro que la biología y la moral ya no se disocian. Las ciencias del viviente acaban de cambiar la relación de filiación. No había nada más decisivo ni más antiguo que el vínculo madre-hijo o su homólogo, el de la paternidad. Han sido refundidos: el lado biológico ha sido disminuido, el educativo y el cultural amplificados. La pareja padre-hijo no por ello ha sido desvalorizada. No sale de estas contestada sino rejuvenecida. El moralista lo único que puede es saludar y celebrar esta suerte de metamorfosis. Se cuidará claramente de no sumarse a los que maldicen el presente y sus cambios.

\section{Capitulo IV}

\section{Prolongar la vida, abreviar la vida}

Muchos filósofos se han inclinado ante la vida, a tal punto ella se ofrecía a ellos como un conjunto imposible de cortar, en el cual todas las partes cooperaban y se armonizaban las unas con las otras. Esta unidad escapaba a la pluralidad. El viviente se inscribía también en el tiempo en el seno del cual se desarrollaba; se colaba en él. Nacemos en un momento dado y debemos morir a una hora que no hemos decretado. El ser vivo entraba en una continuidad indescomponible.

La técnica se opone a lo que es y se dedica a transformarlo; si se aplica a todo lo que es material, se topa con el viviente que le resiste. Si atacamos demasiado a este último, deja de existir y cede a los golpes de la violencia. No podría tolerar lo que lo descompone. Claramente por esto se impone el principio de la sola natura medicatrix (solo cura la naturaleza), o, la influencia de la medicina hipocrática que cuida el cuerpo con respeto. Se inspira en sus exigencias. Busca fortificarlo, pero se cuida demasiado de no imponérsele. Cuando lo transforma, corre el peor riesgo.

Las crisis mismas obedecen a ritmos, o a plazos que no se podrían reducir. Añadamos que una filosofía moderna, y de importancia, se ha esforzado por soldar los dos extremos de la cadena: el bergsonismo no distingue la vitalidad de la duración, a tal punto las dos se hacen una.

Por su lado, el moralista que quiero encarnar aquí no puede más que someterse en presencia de lo que no puede modificar. Está puesto ante un irreductible y un indescomponible. Está obligado a volver su teoría un arma de paciencia y de sumisión, pues se debe soportar "lo que no depende de él".

Por ejemplo, el médico le enseña al enfermo la resignación. No deja de concederle un real reposo -el tiempo de la convalecencia- con el fin de que pueda él mismo restablecerse, restaurar sus fuerzas, favorecer la autoreconstitución. 
Pero he acá que todo se pone a cambiar: la medicina actual abandona su camino tradicional para mostrarse capaz tanto de aumentar el tiempo de la vida, como de reducirlo. La medicina va a disociar y a desmantelar lo que se consideraba -con toda razón- como indivisible. Una tal proeza no deja de conllevar complicaciones de tipo moral, puesto que parecemos profanar lo que, por algunos lados, tocaba la sacralidad (la corporeidad). También, después de haber recordado en una palabra los logros de la terapéutica moderna, me interrogaría sobre lo bien fundado de ellos, y los límites que podrían imponerse. ¿Hasta dónde se puede ir? Entramos en una problemática que funde la medicina y la moral, y que renueva su implicación.

\section{El reemplazo de los órganos vitales}

Una de las proezas de la cirugía actual ha logrado sustituir un órgano esencial deficiente (el corazón, el riñón, el hígado, el pulmón) por otro que se ha extraído de un moribundo. La primera dificultad que encontramos proviene de que el terapeuta no duda en intervenir a un enfermo para curar a otro que está casi en igual caso (la muerte no tardará para él). ¿Es admisible que se pueda transformar un cuerpo -moralmente hablando, y un cuerpo que debemos respetar puesto que el sujeto habita en él- en un cierto número de piezas, piezas desprendibles que se podrán reimplantar en otro cuerpo por medio de injerto?

Desde el comienzo ¿no debería un filósofo inquietarse en presencia de una intervención que mutila el organismo que entra en la muerte? Pues ¿cómo negar que el sujeto está siempre vivo (aunque sea un poco) en sus órganos, que no podríamos separar los unos de los otros, puesto que todos -a su manera- nos expresan?

¿Cómo tolerar lo técnico-inimaginable en el que lo que originaliza al uno se va a alojar (para no decir, perder) en la individualidad del otro? ¿Cómo tratar tan crudamente lo que nos personaliza?

Es verdad -incluso si el argumento parece flojo- que podemos atenuar la violencia de esta transferencia. En efecto, es preciso distinguir el trasplante de un órgano como el corazón, de aquel de algunos tejidos, o incluso de células, que se reforman (como la sangre, el esperma, incluso la leche). Además, algunos aparatos viscerales son dobles (dos riñones), otros fáciles de compartir (los lóbulos del hígado), en fin, algunos se presentan como un conjunto, una colonia, por ello una posible extracción de apenas algunas unidades.

En suma, las extracciones difieren aparentemente por su naturaleza e importancia, cuando no por su gravedad, según que el cirujano busque lo renovable o lo periférico o lo abundante o, a la inversa, lo único y lo central (muy 
particularmente el corazón). Quizá equivocadamente, el filósofo podría tolerar mejor la primera extracción que la segunda. La cuestión perderá un poco de su intensidad trágica; la transfusión de sangre lo evidencia puesto que no concita ningún temor o inquietud.

Otra situación más difícil de aceptar y sujeta a enfrentamientos es la de la mujer que ofrece benévolamente a una pareja estéril el uso de su "útero" (uno de sus órganos). Se convierte en portadora. Para este caso, ella no ha renunciado a esa parte de ella misma, pues lo que cede es solo la función, y no arriesga la más mínima disociación. Además, no se excluye que ella conozca al/o a la que ayuda, mientras que en los trasplantes habituales el anonimato está garantizado. No confundamos las dos operaciones; en esta última, una competencia psicofisiológica no ha sido sino prestada y por un período limitado.

\section{Elogio del trasplante}

La cirugía sustitutiva moderna ha buscado aún reducir sus fracasos recurriendo no tanto a un xenoinjerto (un tejido u órgano animal) o a un heteroinjerto que a un isoinjerto; para asegurar bien el éxito en este último caso, se cuenta con un gemelo homocigótico o, en rigor, con un aloinjerto, pero de fórmula antigénica próxima. Para este efecto, ha ocurrido que existen padres que han decidido dar nacimiento a un niño, llevados por la idea de que este podría servir para salvar al hermano mayor afectado por una grave enfermedad sanguínea. La inyección al enfermo de las células madre sanguíneas extraídas del cordón umbilical o de la médula ósea lo curará de sus graves anemias.

He recordado esta situación porque ella no se pone de acuerdo con la moral kantiana soberana, y a menudo alegada: una persona no debe, en ningún caso, servir de medio con miras a un fin exterior a ella. En este caso, sin embargo, es el medio el que ha entregado el fin. Situación que reencontraremos más tarde; no podríamos separar los dos cuerpos. Aprendamos a no mirarlos ya como separados, puesto que una víscera de uno va a tomar el lugar de la del otro.

Me alegra esta transferencia salvadora que, sin lesionar al uno, permite curar al otro definitivamente.

Reconozco gustoso que, si todo en el cuerpo no merece la sacralidad -especialmente lo que se desprende: los cabellos, las uñas, los dientes, o incluso lo que se reconstituye, como la sangre-, el corazón por lo menos se inscribe en lo más profundo y no debería ser desplazado, casi vegetalmente, del uno al otro. ¿Cómo el receptor podrá por otra parte mantener su identidad, puesto que está tejido de lo mismo y de lo otro, una especie de vestido de Arlequín? ¿Y no se va a dedicar incansablemente a expulsar al intruso, a pesar de los inmunosupresores 
que deben disminuir la respuesta e impedir el rechazo, una guerra intestina y permanente? En resumen, Laceptarán el moralista o el antropólogo que, so color de curar, se pase por un asesinato, porque el terapeuta comenzó por rematar la muerte del que despedaza, pero que conserva, sin embargo, trazas de una vitalidad que no ha sido abolida por entero?

¿No es insostenible que se vaya a sacar de un muchacho que se está muriendo lo que se dispondrá luego en un incurable, con miras a revigorizarlo? Insisto: ¿cómo se va a acomodar el moralista a este reciclaje?

\section{Las condiciones del trasplante}

Antes de pronunciarme por razones morales a favor de esta cirugía excepcional, requiero regular tres dificultades graves que arriesgan con aminorar, o incluso entrabar, la audacia de esta terapia.

Primero, el cirujano debe, ante todo, controlar el más perturbado, asegurarse de la casi-muerte del donador, pues importa evitar el asesinato, en el sentido habitual. Conviene incluso lograr una maniobra acrobática: a pesar de la muerte cerebral (el coma llamado depassé e irreversible), mantener en una vida lentificada lo que será extraído, el corazón, el hígado, etc. Ya se comienza por segmentar el organismo, por descomponerlo en regiones con regímenes diferentes antes de proceder a la separación efectiva; por ejemplo, apoderarse de este corazón que continúa latiendo bien que mal.

Si el especialista se apoya en un criterio reconocido de la muerte (el cerebro ha cesado de funcionar); sin embargo, no podemos silenciar que, para algunos biólogos, el deceso solo es reconocido y avalado a partir del momento en que todas las células han puesto fin a su actividad. En 1800, Bichat nos previno suficientemente de que un tal estado solo llega por etapas: algunas mueren primero, otras mucho después, tanto y tan bien que el final de la existencia se localiza con dificultad.

Es patente que los adeptos del injerto (con el fin de permitir su trabajo resurreccionista) han privilegiado un instante bien circunscrito -y según ellos, decisivo-: la detención cerebral que autentican los registros electroencefalográficos, así como la ausencia de todo reflejo como de la menor actividad motriz autónoma. Los restos de vida podrán incluso ser mantenidos artificialmente por medio de una respiración entubada y presiones manuales sobre el tórax, con el fin de facilitar un cierto movimiento de la sangre. ¿Cómo no temer que esta definición, o esta indicación de muerte, no esté inspirada por el programa de extracción y de su posible licitud?

- 212 
Pero la idea de estados intermediarios entre la vida y la muerte (ella misma escalonada), la existencia de comatosos que habrían regresado a la conciencia después de jornadas de tinieblas obliga, al menos, a la prudencia y a la desconfianza. El filósofo Hans Jonas menciona este problema: "La entrada en juego de un interés, y más aún del interés de otros pacientes, no priva solamente a la definición de su pureza teórica, sino que coloca también su aplicación en el peligroso claroscuro de una tentación animada de buenas intenciones"3.

En breve, la medicina más audaz utiliza la muerte en curso de los unos para volver a la vida a casi-moribundos. Imaginamos sin dificultad los peligros, tanto biológicos como morales, de semejante transferencia: iel corazón del uno en el pecho del otro! El Código de Salud Pública trata de prevenir los más mínimos deslices. Estipula, por ejemplo, que "los médicos que establecen la constatación de la muerte, por una parte, y los que efectúan la extracción o el trasplante, por la otra, deben hacer parte de unidades funcionales o de servicios distintos" (art. L. 671-10, ley del 29 de julio de 1994).

En segundo lugar: no dudo que el cuerpo de un individuo le pertenece, no en el sentido de un simple tener o de una propiedad, sino como lo que lo expresa y lo representa. Descomponerlo y sustraerle sus principales órganos (dejamos de lado la cuestión particular de los ojos) debería implicar, por lo menos, su consentimiento. En Francia, por lo demás, está previsto un registro en el que todos los que se rehúsan a la donación pueden inscribirse.

Se trata acá de una medida particularmente dudosa: pocas personas piensan en la suerte de sus despojos; además, están mal informadas de las medidas administrativas relativas a su semi-cadáver. Por consiguiente, su silencio relativo a la extracción de órganos es interpretado como una aceptación. Las extracciones son toleradas, e incluso preconizadas, puesto que ninguna negativa ha sido registrada, expresada.

El legislador, sin embargo, ha deseado que la familia, así como los parientes, sean consultados, de forma que se pueda conocer mejor la voluntad del difunto. El Código de salud lo precisa: "Si el médico no tiene directamente conocimiento de la voluntad del difunto, debe esforzarse por recoger el testimonio de la familia" (art. L. 671-7). Esta enmienda no modifica el problema, en el sentido en que la medicina no tiene en cuenta para nada al moribundo, cuyo cuerpo cae en el dominio público, a pesar de todas las precauciones.

Sigue siendo claro que el receptor ignorará la identidad del donador: "El donante-según el artículo L. 665-14- no puede conocer la identidad del receptor, ni el receptor la del donante". ¿Por qué esta medida sino con el fin de no indisponer

\footnotetext{
3 H. Jonas. El derecho de morir. París: Rivages, 1996. p. 59. Jonas considera como abusivo tomar la cesación de la actividad cerebral como signo o criterio de muerte.
} 
al beneficiario ni pesar sobre su libertad? Pero, cuando se trata del trasplante de un órgano de una persona viva, está estipulado que la operación no podrá exceder los límites de la familia: "el receptor debe tener la cualidad de padre o de madre, de hijo o de hija, de hermano o de hermana del donante... En caso de urgencia, el donador puede ser el cónyuge" (art. L. 671-3). A falta del anonimato, aquí imposible, el enfermo que se va a curar queda libre -en gran parte- del peso de la gratitud y de todas las complicaciones que nos imaginemos. Solo les deberá a los suyos su salud, lo que fácilmente aceptamos.

Una tercera dificultad espera el injerto: a causa de la falta de tejidos -la penuria-a quién se va a excluir de esta terapia excepcional: ¿a los extranjeros, los indígenas, las personas de una etnia diferente, aquellos cuya vida social parece la más miserable (los desfavorecidos) o también a los que tienen mucha edad? Dos concepciones se enfrentan: la una preconiza la eficacia, a nombre de la cual los pacientes que presenten el mejor pronóstico serán tenidos en cuenta. La otra defiende la igualdad, pero el rendimiento de la intervención resultará rebajado. ¿No debemos también darle ventaja al más próximo del centro hospitalario, con el fin de ganar la batalla de la rapidez (los minutos cuentan) o aquellos cuya diálisis ya se realiza hace mucho tiempo (en el trasplante de riñón)? A veces, hay que atenerse a una determinación que fuerza la decisión: los órganos del joven donador no convienen sino a un receptor particularmente delgado; es menester entonces respetar las proporciones o dimensiones, es decir, la casi-similitud de volumen entre lo que se toma y lo que se recibe.

La autorización de extraer solo les es concedida a algunos raros establecimientos. El director de la Agencia regional de la hospitalización, actuando a nombre del Estado, precisa incluso el tipo de órgano que el establecimiento puede pretender. Nos podemos reconfortar -moralmente hablando- de que el cuidado de proceder a las selecciones y al respeto de ciertas prioridades le haya sido confiado al Establecimiento francés para los trasplantes, aunque él debe sin duda decidir caso por caso, a tal punto hay parámetros numerosos que entran en juego. No se puede estar seguro de que él encuentre la mejor solución. ¿Qué criterio debe imponerse? Pero ¿por qué saludar la importancia de nuevo reconocida a lo que es público, y a una comisión nacional?

En principio esta comisión debería rebasar los intereses particulares, e imponer una solución más en armonía con la salubridad del conjunto. No olvidemos que los intereses de los unos son, por definición iopuestos a los de los otros!

\section{Algunas reglas que hay que respetar}

Acabo de exponer tres situaciones previas de naturaleza socio-moral que pesan sobre esta cirugía resurreccionista, enzarzadas en consideraciones deontológicas:

- 214 
1. ¿Está verdaderamente muerto el donante, aunque deba conservar las trazas residuales de vida (una ventilación mecánica se le debe suministrar, y un mínimo de función hemodinámica se ha conservado)?

2. ¿Ha aceptado que su cuerpo sea despedazado y que sean transferidos sus principales órganos?

3. ¿Quién recibirá este don? ¿Quién merece beneficiarse de él?

Los adversarios del trasplante insisten en la gravedad de estas tres preguntas que cuestionan las bases de una medicina que explota la muerte y no retrocede ante ningún obstáculo, especialmente el respeto debido al cuerpo que entra en un coma.

¿Por qué es preciso aprobar con entusiasmo esta cirugía incorporativa? ¿En qué esta -que de ninguna manera promueven los principios de la moral- logra ella, por el contrario, suscitar una nueva y generosa humanidad? Será quizá que la verdadera moral se burla de la moral, isegún la expresión de Pascal!

\section{La compenetración de los cuerpos}

El recurso al trasplante marca una revolución sin precedentes en la historia de la medicina. Hasta entonces, el drama de la enfermedad ponía en presencia a dos actores, el paciente y el terapeuta, en el famoso coloquio singular. Por lo demás, hubiera podido, si no debido, introducir aquí una tercera persona: el enfermero o la enfermera, siempre presente, y cuyo papel no ha dejado de acrecentarse. Pero muchos de los comentaristas no han seguido a los clínicos que estaban dispuestos a esta ampliación, aunque todos no estén listos.

Podría insertar en este encuentro a un cuarto personaje, aunque él no siempre interviene en esta consulta; más bien en lo que la prepara y la sigue: el representante de los que están afectados de la misma patología porque todos reivindican los mismos derechos, las mismas medidas.

En todos los casos, con el trasplante, otro personaje entra en escena: el donador. Correlativamente, el medicamento tiende a ser menos importante a no ser que sea bajo lo forma de los inmunosupresores. La transferencia de un órgano -o de células- aún ligado por un hilo a la vida está aceptada y asegurada.

La curación vendrá del intercambio biomaterial. Una especie de intersubjetividad se instituye a través de esta bio-sustitución salvadora.

Los enemigos del trasplante continúan argumentando en una perspectiva individualista, para no decir incluso subjetiva: el corazón, el hígado, el pulmón son siempre definidos como bienes propios. Defienden una insularidad que 
impide precisamente la entrada en lo que se podría llamar una hiper-humanidad. Aquí, la biología accede a una especie de comunidad; lejos de temer una entrada del otro en sí, la cirugía trabaja en la circulación. iY se podría casi hablar de cuerpo místico! Se atenúa la potencia de las fronteras que aíslan el ego de sus allegados.

Se me objetará que el donante ha cesado prácticamente de vivir, y que la comunidad -a causa de la compenetración orgánica, que celebramos en sordina- se ha vuelto imposible. Es olvidar que estas intervenciones suponen al donador aún con vida (sobre todo al que ofrece células madre de su médula), y que en todos los casos la terapia recurre a órganos o a biomateriales que son perfectamente funcionales, teniendo una sorda identidad con el receptor (una histocompatibilidad o una similitud antigénica, la pertenencia a un mismo grupo tisular). Es pues un poco "lo mismo" -lo parecido al menos- que va a tomar el lugar de lo mismo. No acentuemos demasiado las distancias porque, de esta manera, terminaremos desconfiando de la filosofía de esta terapia y nos la imaginamos entonces como los cuerpos encastrados los unos en los otros, como si no pudieran ya reivindicar un mínimo de especificidad.

Evolucionamos en un espacio donde se cruzan una vida que se muere y una pre-muerte, dos estados que se corresponden; una pre-muerte que conserva vida, a nombre de la cual toma el relevo de lo que ya no puede ser revigorizado, en momentos en que solo la inter-corporeidad puede asegurarnos la salud. Insisto en el hecho de que la curación del receptor por parte del donante viene de que el uno está parcialmente vivo y el otro parcialmente muerto. Lejos de interrumpir su actividad, el corazón que se le retira al comatoso prosigue su vida en el pecho que lo acoge y donde va a enfrentar una nueva existencia. Las antiguas terapias recurrían siempre a sustancias o a productos corporales sintetizados, pero permanecían estando exteriores al mal o a la función que apaciguaban o recuperaban. Aquí, la cirugía salta el paso: sustituye el aparato desgastado por la potencia de uno más joven. Nos da un cuerpo nuevo, el más próximo posible del precedente.

Notemos otra transformación que este biomaterial entraña. Ayer, la moral comandaba a la medicina, le fijaba su línea de conducta (el Código de deontología), y la sometía a deberes; en caso de que no los respetara, se comprometía el ejercicio de su arte. De aquí en adelante -sin que estas obligaciones se hayan abolido- estamos un poco más dedicados a lo inverso: la terapia de la prótesis viviente nos sugiere otra humanidad más cooperadora, instituye una compenetración de los cuerpos que anuncia, y ya prefigura, la de los espíritus. En suma, la medicina se somete aún a una moral, pero una nueva moral se pone también a derivar de sus audacias salvadoras. 
Continúo regocijándome de que el Establecimiento francés de los trasplantes controle el conjunto de ellos. Vigila tanto lo que precede como lo que lo sigue. Entramos en una medicina rodeada de colectividad. El cirujano no podrá recibir honorarios. El dinero está desterrado de aquí. "Ninguna remuneración puede ser cobrada por los médicos que efectúan trasplantes de órganos a título de esas actividades" (art. L. 671-17; ley del 29 de julio de 1994).

Nunca moral y medicina se habían cruzado mejor; es verdad que esta ha llegado a tocar el transfondo del organismo y lo que resulta ser la base de la personalidad (el propio cuerpo en su funcionalidad). Los progresos de la biomedicina van a liberarla felizmente de su peor limitación: podremos entonces tanto extraer órganos esenciales como reponerlos en otro lugar. La clonación terapéutica, en plena evolución, va a proveernos los biomateriales deseados, por caminos sin riesgos.

\section{La clonación terapéutica}

Puesto que trato del trasplante bajo el ángulo moral, me es imposible en efecto silenciar el logro más reciente: la clonación terapéutica que, más que cualquiera otra, hace parte de las cuestiones prohibidas.

El filósofo que soy no puede sino alegrarse de entrar en una discusión ardua y rica en sub-entendidos; nunca la teoría moral y sus principios habían sido tan solicitados como para este problema.

¿De qué se trata? El biólogo parte de una célula sexual femenina (un ovocito) sacada de una mujer que estuvo de acuerdo. Se le quita el núcleo (con $n$ cromosomas) para reemplazarlo por el de una célula madre somática (con $2 n$ cromosomas), sacada del paciente que se beneficiará de la continuación de las operaciones. El biólogo estimulará este nuevo conjunto.

¿En qué reside la innovación? Un embrión, regularmente formado, resulta de la unión de un ovocito y de un espermatozoide, cada uno con $n$ cromosomas; al poseer los dos $2 n$ cromosomas -debido a la mixtura- entrará en su propio desarrollo embrio-fetal. Pero, en la clonación terapéutica, si (al recurrir a una célula con $2 n$ cromosomas) se satisface una exigencia de la fecundación, la entrada en el ovocito enucleado de un núcleo somático engaña de alguna manera al citoplasma de acogida; el proceso embrionario se desencadena, a tal punto que el núcleo extraño va a des-diferenciarse (estaba débilmente diferenciado). Le serán comunicadas capacidades regeneradoras, los recursos de la primitividad o de la juventud; se obtienen células madre.

Estas células, que acaban de entrar en el ciclo divisionario (deben alcanzar el estadio blastocisto), podrán entrar en el tejido de cualquier órgano deficiente 
del donador (que ha facilitado el núcleo somático), por una parte, porque ellas han perdido su antigua orientación y, por otra parte, porque las células de un tejido cualquiera no dejan de enrolar a aquellas (regeneradoras) que entran en él y no se oponen a la nueva funcionalidad. El órgano saldrá de acá renovado.

Desde el punto de vista epistemológico, voy a subrayar que, en las dos operaciones evocadas, asistimos al mismo procedimiento de base, el del poder modificador de las unidades las unas sobre las otras; por un lado, la posibilidad para un ovocito (aunque enucleado) de reorientar un núcleo; del otro, la asimilación de la célula restauradora (reviviscente) al conjunto tisular donde tomará lugar.

De paso, no dejo de concederle un papel (en la trasmisión) al citoplasma de la célula, a lo que rodea el núcleo, a lo que el genetista no siempre le pone cuidado. La prueba de este error está dada aquí: la célula germinal enucleada continúa actuando. Pero, sobre todo, (en una desviación más cargada de consecuencias) el biólogo encara demasiado separadamente los juegos celulares, mientras que las unidades no cesan en realidad de doblarse las unas sobre las otras.

Señalemos que el experimentador puede también utilizar otro tipo de célula, una célula de embrión, de la cual toma su fuerza generadora. Le quita su núcleo, pero le pone otro que va a desarrollar, impulsar.

El moralista está tentado a condenar este desvío porque el embrión sirve de depósito y tiene acá el papel de un medio: comunica a la célula ordinaria su potencia multiplicadora.

Es olvidar que en el caso de la fecundación in vitro, por ejemplo, el ginecólogo está obligado a puncionar muchas células sexuales (ovocitos) porque corre el gran riesgo de tener que retomar sus tentativas de fertilización. Le es precisa una reserva; no puede recomenzar a operar bajo anestesia para procurarse gametos. ¿En qué se convertirán entonces los embriones, obtenidos después de la fecundación, que no han servido (los embriones supernumerarios)? El legislador exige su destrucción, pero ¿cuál es la mejor solución sino la que va a utilizar las potencialidades de lo que ayer se eliminaba?

Es obvio que el tipo de clonación celular que acabo de evocar autorizará un auto-implante (el injerto de sí en sí mismo) sin riesgos inmunitarios (el rechazo), puesto que la neo-célula madre posee el mismo patrimonio que el receptor del que ha salido. Nadie discute las ventajas ni la importancia curativa de esta técnica.

Pero las reticencias vienen de algunos médicos que se quieren humanistas, y sobre todo de la mayor parte de los moralistas particularmente enojados, que se suman a la tropa de los tecnófobos. 
Uno de los argumentos utilizados consiste en sostener, primero, que la biología acaba de tomar un camino que va a conducirla a la clonación reproductiva, porque la una -la terapéutica- diverge poco de la otra -la reproductiva-. Esto último no puede sino ofuscar al filósofo, incluso si ello es más una amenaza que una realidad. Sirve a los enemigos de la Modernidad que lo blanden como si se inscribiera en el programa de la ciencia que se vuelve condenable en bloque. ¿De qué se trata? En lugar de recurrir al núcleo de una célula de un paciente, será suficiente con tomar un núcleo cualquiera sobre aquel que se quiere reproducir tal cual (para obtener el clon). La experimentación ha tenido ya éxitos en el pasado, en el animal (la oveja Dolly en 1997).

Efectivamente, la clonación reproductiva tiene que ver con lo inaceptable: ¿por qué engendrar al sujeto a partir de sí mismo y, sobre todo, idéntico a su genitor? En verdad, con él, ya no sabríamos dónde reside el original, a tal punto el doble copiaría el modelo, lo multiplicaría incluso y, por ahí, lo anularía en tanto que tal.

Esta aparente proeza conduce a matar la vida, que siempre ha privilegiado la diversidad y la autenticidad, la originalidad. Nadie es igual a otro, e incluso los verdaderos gemelos divergen. Ya Leibniz pensaba que dos hojas de un mismo árbol divergen entre ellas; las diferencias estallan por todas partes. El moralista debe pues desviarse de este espejismo de la clonación. La reificación se le impondría puesto que se sometería el viviente a la repetición, a la estandarización; sería confundido con un objeto, que puede, sin duda, ser producido y reproducido.

El proyecto narcisístico, y por tanto patológico, del recomienzo de sí, se condena tanto más cuanto que el biólogo no lograría recomponer lo mismo, sino solamente un "casi lo mismo", un mismo sesgado e incompleto, porque será fabricado un individuo a la vez joven y viejo: lo primero en razón del proceso operatorio, lo segundo puesto que el imitado es un adulto. En esta última perspectiva, vamos hacia lo monstruoso.

Pero la clonación terapéutica no podría ser acercada a la reproductiva; en caso contrario nada sería condenable; cualquier cosa puede ser pervertida y viciada. Mientras que el moralista debe impedir lo uno, puede privilegiar y valorizar lo otro.

El opositor de la clonación terapéutica mantiene, sin embargo, que el ovocito, destinado a la creación embrionaria -la vía sagrada de la vida- ha sido desviado de su verdadero papel y dedicado a una tarea exterior a él (así sea la salvación de un tercero). Se ha vuelto medicamentoso; a causa de esta manipulación, entró en un movimiento de fabricación. Pero yo veo acá un alegato partidista y falseado. 
Para comenzar, la medicina (así como la legislación) admite, entre otros, el IAD: el esperma de un donante anónimo suple el del esposo estéril. ¿No ha sido transformada la sustancia generadora en "medio" con miras a un fin que le es ajeno? ¿No se pone en acción una especie de fábrica de reproducir? Se me opondrá que esta inseminación trabaja por un nacimiento, mientras que la clonación terapéutica lo que busca es un renacimiento (el de un enfermo del que asegura su curación, la regeneración).

Luego, conviene precisar los términos: el ovocito no equivale al embrión. El biólogo se atiene a los primerísimos estadios de la división llamada embrionaria; utiliza una capacidad celular, no un ser. La clonación terapéutica no implica un nacimiento, y mucho menos cuanto que se limita a desviar, como se lo ha visto, el movimiento del ovocito que es, por así decirlo, engañado.

Finalmente, lo peor consiste en clausurar la biología sobre sí misma, en no permitir el menor desbordamiento. Siempre he tomado el partido de lo cultural y de lo meta-humano; moralmente hablando no considero que me deba alinear sobre lo orgánico y su necesidad; y el rechazo de la clonación terapéutica supone dos pesados dogmatismos: el que impondría lo corporal al cual uno debería someterse, y el de una genética actualmente absolutizada, que refuerza el precedente.

No olvidemos que la mujer le ha concedido al biólogo el derecho de extraer de ella la célula que le dará la vida al enfermo. Le concedo valor a esta especie de simbiosis de los cuerpos que se prestan asistencia los unos a los otros, una asistencia que permitirá la suplencia. Que nadie sostenga que el uno sirve entonces de "medio" para un fin que concierne "a otro" (una manera kantiana de evaluar). Recuerdo, además, que los padres han querido y han concebido un niño con el fin de que pueda aportar a su hermano enfermo las células isocompatibles que no habían encontrado en otra parte. ¿Quién se ofuscará por ello? La clonación terapéutica se parece a esta acción de afecto.

Por otra parte, el teórico hostil a la novedad (sin embargo, más moralista que la moral de la tradición) quedará de nuevo privado de su principal argumento, a tal punto el experimentador acaba de renovar su práctica; de aquí en adelante, podrá eximirse de la célula embrionaria. Se limitará a aislar "células madre" en el propio sujeto. Por ejemplo, en el caso de la piel, las células menos diferenciadas que se encuentran en la base, en la profundidad de la dermis, reforman las de la superficie, las que se exudan. ¿Cómo procede el biólogo? De las células somáticas aparta las más activas, las multiplicadoras, y las somete a un tratamiento: un baño en compuestos reductores, antioxidantes, con el fin de lograr la transdiferenciación. Ellas salen de él sometidas a una inversión, deslastradas de su débil especificidad, después de lo cual podrán convertirse 
en neuronas si se las inserta en un tejido nervioso, al que revitalizarán. ¿Cómo la piel puede producir células cerebrales? Porque las dos derivan de la misma hoja y se generan a partir del mismo ectoblasto.

Esta clonación celular revolucionaria -lo mismo que reforma lo casi-mismose inscribe en el principio farmacodinámico mayor: los verdaderos remedios se inspiran en el cuerpo y por esto son activos. "Lo otro" permanece exterior y por tanto poco eficaz. Los verdaderos medicamentos utilizan el cuerpo por sí mismo, con él y a veces contra él, cuando se trata de moderar un dispositivo funcional.

En este último caso -la célula madre que sustituye la embrionaria con miras a la restitución histológica-, el problema moral pierde su agudeza. Es uno de los argumentos de los opositores de la clonación terapéutica, que sostienen que el biólogo puede obtener estas células madre por vías naturales; el biólogo puede (y debe) ahorrarse su violencia experimental. Pero a pesar de las promesas de esta nueva práctica ¿es seguro que pueda entonces obtener también buenos resultados? No estoy completamente convencido.

Si es verdad que esta terapia no le conviene de ninguna manera a enfermos que viven sus últimos momentos pues, para ellos, siempre se requiere un implante viviente, un corazón rápidamente transferido, recordemos que la reprogramación celular (la clonación terapéutica) no se limita a remendar el cuerpo, sino que participa en una especie de rejuvenecimiento y de recreación.

El moralista puede alabar esta actuación tanto más cuanto que ni el corazón del moribundo ni los fragmentos de un feto han requerido contribuir. Las dificultades que señalaba al comienzo han desaparecido, por ejemplo: el consentimiento del donador de tal o cual órgano. La cirugía renuncia a lo que podría parecer-equivocadamente por lo demás- violento, para no decir: bárbaro.

A fin de cuentas, la razón de la oposición a este implante (el sí por sí mismo) implica no tanto consideraciones morales como una actitud política: el político gana diabolizando esta proeza. Ve un trabajo de Mefistófeles que viola las reglas soberanas de la naturaleza. Los hombres prefieren lo viejo a lo nuevo, lo natural a lo artificial, lo conocido a lo que solo está en curso.

La ciencia interviene de aquí en adelante ya no sobre la materia sino en las fuentes de la vida; no respeta ya más los valores, los va a enredar. El demagogo encontró acá lo que le gusta a la gente. Pero es preciso no ceder. Que al menos se vote una moratoria, exige el opositor; en efecto es una solución perezosa que puede contentar a los unos y a los otros. No se le ha dicho no a una legislación que autorizaría la clonación terapéutica, pero tampoco se le ha dicho sí. En los Estados Unidos se desarrolló una trapacería: las instituciones que tienen que ver con el Estado no pueden entregarse a estos experimentos relativos a la clonación, 
pero a los laboratorios privados no siempre les concierne la prohibición. Más vale evitar tanto una como otra hipocresía.

\section{La eutanasia}

Examiné en sus grandes líneas la hazaña de los que logran prolongar la vida gracias al implante revivificador. Terminaré con la evocación del problema inverso, y de sus repercusiones morales: el de una medicina que la abrevia. Entro en el análisis del asesinato eutanásico.

Ya el aborto -obra de muerte- fue antaño sancionado. Recordé anteriormente la existencia de un período que lo penalizó fuertemente. La pena de muerte podía ser solicitada contra el que lo había practicado. ¿Cómo no estar chocado por el hecho de que el médico derogue el principio del No matarás? Da la muerte al que debía curar, o al que le debería facilitar la venida a este mundo. Recordé que, para algunos, no era lícito sacrificar al hijo practicando un aborto terapéutico para salvar una madre. Se considera la supresión del feto como un asesinato. Pero en nuestros días, la ley nueva autorizó la IME (la interrupción médica del embarazo). A pesar de esta apertura, la sociedad persiste en censurar -para no decir: castigar- a los que, en lugar de favorecer la vida, permiten la muerte o la precipitan. Parece excluido que el médico pueda pactar con lo que, por el contrario, y sin descanso, él debe combatir.

\section{También se impone la prudencia}

Insisto sobre dos actitudes que continúan prevaleciendo: según la primera, en nuestras culturas el suicidio arrastra la condena. Es vituperado porque el momento de la muerte está fijado por el destino. El que se suprime (y sobre todo: que el médico no se proponga ayudarlo) nos priva y se priva del bien que es la vida. En la Edad Media estaba prohibido sepultarlo; su alma no conocía el reposo sino el vagabundeo. A esta pena corporal se le sumaba la confiscación de los bienes. Los nobles eran degradados y su escudo roto. Peor aún: el homicida de sí mismo era previamente arrastrado, la cara contra la tierra; luego colgado por los pies antes de ser abandonado, echado a los carnívoros. Desde el siglo XVIII, Beccaria protestó contra una sanción que solo toca a un cuerpo insensible, y que solo afecta a los miembros de la familia, por tanto, a inocentes. Incluso no era seguro que ella disuadiera a los que estuvieran tentados de imitar a esos "cobardes".

Poco a poco la sociedad renuncia a su severidad; acepta amortajar esos cuerpos. La Ley municipal del 5 de abril de 1884 prohíbe incluso inhumar a los suicidas en un rincón especial del cementerio. Una Ley de noviembre de 1887 estipula que los suicidas podrán beneficiarse de disposiciones legales relativas 
a los funerales, ya sean religiosos o civiles. La reprobación con respecto al que se ha dado la muerte subsiste, sin embargo, y sus descendientes siguen siendo señalados con el dedo.

La segunda actitud concierne al terapeuta, que no podría trabajar en lo que destruye. A lo sumo podrá preconizar analgésicos y ansiolíticos que suavicen este período temible. Si tiene prudencia, el clínico ganará con ello en dignidad (solo piensa en prolongar la vida), pero también en competencia, a tal punto su disciplina evoluciona rápidamente.

Se cita a menudo el caso de un médico que puso fin a los sufrimientos de su hijo, en el mismo momento en que se enteraba del suero elaborado por Émile Roux. Más tarde, las sulfamidas y los antibióticos llegan al mercado, y la estreptomicina acaba con la meningitis tuberculosa fatal. En 1946, la endocarditis mortal cede a la penicilina. Excluyamos pues que la incurabilidad de una afección vaya a ser absoluta, lo que impone la obligación de informarse y de saber esperar la venida de la panacea.

Existe sobre todo una actitud que no puedo aceptar, en razón de su hipocresía (el doble juego): la prescripción de antálgicos en dosis tales que producen la intoxicación. El clínico evita las molestias administrativas, así como los escrúpulos deontológicos -él predica lo que reconforta al enfermo que sufre-, pero no ignora que el medicamento (con fuerte posología), se transforma en su contrario. El tratante juega a la compasión a través del acto por el cual provoca el fin de su paciente. El Código querido de su profesión le subraya claramente: "El médico debe esforzarse por apaciguar los sufrimientos de su enfermo. No tiene el derecho de provocar deliberadamente su muerte" (art. 20, título 1. ; Sobre los deberes generales de los médicos).

La moral de Kant, más enérgicamente aún, condena severamente tanto el suicidio como una muerte que hubiera sido provocada: "El hombre no es ninguna cosa; por tanto, no es algo que pueda ser usado meramente como medio... No puedo disponer del Hombre en mi persona para mutilarlo, pervertirlo o matarlo" (Cimentación para la metafísica de las costumbres, cap. II) ${ }^{4}$.

Ninguno de los dos análisis precedentes me convence; finalmente, uno y otro buscan prohibir la eutanasia que yo preconizaría, pero bajo ciertas condiciones. Buscaré precisar lo que espero moralmente del médico, en este momento crítico y en presencia de una enfermedad que no logra controlar.

Primero: las disciplinas médicas actuales saben distinguir con seguridad -no era el caso hasta ayer- las diversas etapas de una evolución patológica. Nadie

4 Kant. Op. cit. Buenos Aires: Aguilar, 1968. p. 126. 
puede negar que la entrada en la muerte se reconoce por la afectación cerebral irreversible. La extinción de lo sensitivo seguirá, y finalmente el ataque a lo vegetativo. Una respiración artificial, una circulación mantenida bien que mal, podrán prolongar la ilusión de un sostenimiento, aunque nadie se engañe en el asunto. Esta abolición de lo cognitivo y de lo consciente será fácilmente confirmada por el examen y el trazado electroencefalográfico que se ha vuelto una línea plana, al que se añade la cancelación de los reflejos. La biología renunció a su criterio y precepto ancestral según el cual las detenciones del corazón, y por tanto, de sus ruidos indicarían el fin de la existencia.

Se me podría plantear una objeción. Equivocadamente o con razón, acabo de señalar una especie de límite a partir del cual la vida se retira sin retorno, mientras que anteriormente yo había desarrollado la tesis de una muerte siempre difícil de precisar, o incluso de definir, suponiendo muchos momentos o fases, no pudiendo ser identificada por un signo, o un estado o una deficiencia. Para ello había recurrido a Bichat y a su célebre texto de 1800, Investigaciones fisiológicas sobre la vida y la muerte, en el cual él se rehúsa a una concepción monolítica:

[...] La vida animal es la primera que cesa en la muerte natural [...] La muerte natural termina casi enteramente la vida animal, mucho tiempo antes que lo orgánico termine. Véase al hombre que se extingue al final de una larga vejez; muere al detal, sus funciones exteriores terminan las unas después de las otras ${ }^{5}$.

Pero si se lo examina, se verá que mis dos respuestas no se contradicen. Si sigue siendo verdad que la muerte llega por grados, y que no podemos fácilmente localizar el momento terminal -desaparecemos a través de una sucesión-, ello no impide que no podamos dudar sobre el comienzo de este proceso y de la constatación (confirmada por los exámenes ad hoc) de que la persona enferma entra en su fin. Esto puede eventualmente permitir al clínico adelantarse a lo que va a producirse irremediablemente sin que él pueda ser sospechoso de una intención homicida o inhumana.

Segundo: yo autorizo al médico a no prolongar la agonía; en caso contrario, él transforma al moribundo en "medio": el que debe someterse a las modificaciones naturales ineluctables.

Si el médico rechaza esta eutanasia rigurosamente negativa -la única que yo puedo moralmente sostener-, no escapa a una neurosis de dominación, a tal punto sus aparatos sustitutivos y su arsenal terapéutico (entubado, ventilación, transfusión, coctel medicamentoso) manifiestan su potencia, como si él se negara a reconocer sus límites.

5 X. Bichat. Op. cit. París: $3^{a}$ ed., 1805. p. 143 (en el art. 10: "Sobre el fin natural de las dos vidas"). 
No se trata de defender la eutanasia homicida (asesina) sino la negativa, la que renuncia al encarnizamiento terapéutico, porque su casi-vanidad es entonces reconocida. Ella no prolonga la vida, sino que retrasa más o menos la hora de la muerte. iQue el médico no se encierre en el inmovilismo! Sobre este capítulo, la medicina ayer no charlaba para nada. Excluía de sus filas a un casi-asesino, al que le "ayudaba a la muerte"; y con toda razón puesto que, en esa época, la clínica no tenía medios para indicar su comienzo irreversible.

Pero yo debo ser coherente. De un extremo al otro he evocado y alabado el papel del Estado, de su legislación, pues él encarna lo racional, lo que desborda los intereses individuales y conflictivos. Si le concedo al médico el derecho de interrumpir los cuidados (la eutanasia pasiva), someto -como se debe- una tal decisión al cuadro y a la instancia reglamentaria. Los Países Bajos (que acaban de despenalizar la eutanasia) -una eutanasia, es verdad, activa, en el sentido en que los médicos le procuran al enfermo una muerte suave-, han exigido, sin embargo, el respeto de tres condiciones:

a) la petición expresada por el moribundo, solicitud explícita o latente, incluso inducida;

b) la ausencia de alternativa terapéutica;

c) el consentimiento favorable de un segundo médico, en lo posible juramentado.

De este modo, de nuevo, yo me alejo del coloquio singular, ese pilar de la medicina individualista y liberal, del que me he apartado de comienzo a fin de mis análisis, puesto que el Estado se ha de inmiscuir en la decisión, controlarla y someterla a restricciones.

Ya dudo del consentimiento que no haya sido dado con conocimiento de causa, pues se puede pensar que la opacidad intelectual impide que se haya escogido libremente. Por lo demás, cuando los padres que responden por el menor -a la vez porque es menor y porque está ya inmerso en la inconscienciase oponen a esta muerte programada, el médico holandés está autorizado a pasar por encima de este veto parental; a tal punto parece necesario provocar una muerte rápida dado el estado y los sufrimientos del pequeño paciente. El médico comprende la negativa del padre y de la madre, pero él cree que no tiene que acompañarlos en su desazón. La Ley protege y permite pues el suicidio medicalizado.

Me alejo de esta solución que repruebo. Solo puedo aceptar la eutanasia negativa, es decir, la que no da la muerte, sino que se niega a prolongar una vida que ya no lo es. Me opongo tanto más a esta legislación holandesa cuanto 
que las condiciones fijadas por la ley carecen de consistencia: por ejemplo, se exige la no existencia de alternativa terapéutica, pero estos cambios pueden sobrevenir en este dominio de modo súbito. Maligno quien pudiera preverlos y apoyarse en la imposibilidad de un recurso salvador.

Es necesario aceptar ir lejos en y con el cambio, con el fin de vivificar la moral y ponerla de acuerdo con los recursos de su tiempo, pero también han de existir límites que no deben ser franqueados.

\section{Conclusión}

\section{La revolución en curso}

Nunca tomaremos suficientemente en cuenta el indiscutible dato siguiente: el final del siglo XX marca una transformación sin precedentes de la medicina, tal que nadie podría haberla imaginado, y mucho menos anticiparla. Destacaré tres proezas a título de muestra de este cambio:

- el implante: el cirujano cambia el órgano vital de un receptor (corazón, hígado, pulmón) por el de un donante;

- la inseminación: de una mujer con el esperma crioconservado de un donante anónimo;

- la interrupción de un embarazo que impide el nacimiento de un niño portador de graves malformaciones evidenciadas en la ecografía.

Podría añadir el reemplazo de una arteria trombosada, por un conducto en materia plástica, que asegure la función circulatoria; lo que nos aleja de los célebres análisis de René Leriche (teñidos de un poco de romanticismo) que le reservaba al solo simpático (sistema nervioso) el juego distributivo (la vasodilatación, gracias a la amputación de las constricciones).

Para dar una ilustración más actual, y sobre todo más radical todavía, podría hacer referencia a la clonación terapéutica: la inserción del núcleo de una célula somática en un ovocito previamente enucleado, de tal manera que un individuo podrá recibir (y no rechazar) células capaces de anular la deficiencia que padece.

Grosso modo, la medicina se pone a comandar el nacimiento como a retardar la hora de muerte; logra de ahora en adelante intervenir en los dos extremos de la vida. El implante confiere a su beneficiario, próximo del fin, una nueva juventud.

Notemos que estos éxitos no se limitan a modificar la comprensión de lo biológico y de las operaciones sorprendentes que se realizan sobre él, sino que modifican indirectamente las bases de la sociedad, así como las del individuo. 
Tocan a la familia, al estatuto del cuerpo, al nacimiento y al lazo social mismo. Trastocan el derecho y llegan incluso a conmover los dogmas religiosos.

En estas condiciones ¿cómo estas intervenciones, por completo nuevas, no modificarían la deontología, disciplina que aconseja al médico, y se preocupa de las cargas que de aquí en adelante pesan sobre él?

El código que, ayer, legislaba para la profesión consistía esencialmente en el respeto de la vida, y por tanto de la naturaleza; por esto una interrupción voluntaria del embarazo pudo ser considerada como un crimen. En ningún caso, el discípulo de Hipócrates participaría en una tal intervención. Asimismo, el trasplante no podría ser seriamente encarado, a tal punto el organismo se opone a todo lo que no esté conforme con su especificidad (él combate "lo otro", e incluso lo próximo). Por lo demás, la medicina que se apoya sobre este fundamento -la naturaleza- no tanto lo ha escogido, sino que se lo ha impuesto como el único posible.

Por otro lado, el enfermo sabía y padecía los límites de una terapia que no podía nada hacer contra un nacimiento golpeado por pesadas discapacidades, ni contra una muerte quizá lenta, pero ineluctable (como consecuencia de una insuficiencia importante).

Médico y enfermo, por razones diferentes, se atenían aquí a una moral de la sumisión (lo que depende de nosotros, el resto constituye aquello ante lo cual es preciso inclinarse). La medicina lo más que puede llegar a hacer es retardar un proceso, disminuirlo, en el mejor de los casos: favorecer su aceptación.

Por lo demás no veo para la medicina otro programa diferente al que, en la dedicación, alivia y socorre. Y esta teorización médica -acompañada de su deontología- se rodea de reglas que la consolidan y la explicitan; el respeto debido al cuerpo humano implica que ninguna operación tendrá lugar sin el consentimiento del paciente (una palabra que tenemos que recordar) que le brinda su confianza al galeno. Con esta concepción que se opondrá también a intervenciones arriesgadas, el acto médico se envuelve todavía con las nociones de libertad y de humanismo (palabras precisamente valorizadas, pero que solo privilegiaría a medias, a causa de su contenido demasiado vago, siendo la prueba de ello que ellas podrán ser utilizadas también para calificar a una teoría diferente que expondré ulteriormente).

\section{La sociedad se interpone}

Nada hay en este dominio que no se haya movido, puesto que lo imposible ayer, se muestra hoy realizable. ¿No estará entonces cuestionado todo el sistema? 
Se me podría inmediatamente objetar que los principios permanecen y que la práctica, aunque nueva, audaz y eficaz, no podría descalificar una teoría de los valores, y mucho menos promover una "moral" a su favor. No es la acción la que debe contar, sino el espíritu que la anima. El pragmatismo (con él, solo juega el "hacer") no podría imponerse; él conduce a lo peor, puesto que puede entonces justificar cualquier cosa, a nombre del éxito. Sigue siendo verdad que el antiguo código de los deberes médicos -bajo un aire particularmente atrayente- se inspira en una filosofía bastante miserable, en todo caso precisamente fechada; según ella, sería necesario plegarse a la naturaleza, alinearse sobre un determinismo que nos anula. Lo humano, la cultura, contaría poco. ¿Acaso no se define el hombre sobre todo por el hecho de que puede rebelarse y oponerse a todo lo que sobre él pesa? Ya Descartes nos pedía que fuéramos "amos y poseedores de la naturaleza".

Por lo demás, ante un tal trastorno, los centros hospitalarios se apresuran a constituir círculos de reflexión que -en presencia de situaciones insólitaselaboran nuevas reglas que deberán cumplir los médicos. Y, por su lado, los enfermos mejor informados se asocian con el fin de defenderse contra eventuales negligencias, insuficiencias o, peor aún, un dejar-pasar del que acusan a los clínicos que no han recurrido a lo que la neotécnica imponía. A veces incluso se cuelan acá causas financieras; un tipo de análisis o de tratamiento es mantenido mientras que se multiplican los fracasos o las quejas; el asunto de la sangre contaminada lo ha verificado ampliamente.

Pero lo peor no se encuentra ahí; viene de que, frente a las posibilidades de la terapéutica actual, la medicina trata de mantener sus principios seculares como la naturaleza que hay que respetar, o el individualismo exacerbado, mientras que la biopatología no ha dejado de escapar de allí donde se la había encerrado.

Es verdad que el derecho -presionado por los cambios- piensa cuestionar las prescripciones de ayer; para que se evite ir demasiado lejos, él predica o admite hábilmente algunas concesiones importantes. Se apresta, por ejemplo, a autorizar la adopción por parte de un soltero homosexual, lo que la mayor parte de los países europeos ya han ratificado, dado que pesa mucho este factor haciendo que parezca difícil rechazar aquí lo que se permite allá.

En un primer momento, quiero poner de relieve la evicción o, al menos, el alejamiento de deberes que hasta ayer estaban consagrados; entre las normas casi absolutizadas contaba la obligación del secreto (inviolable) -a tal punto se imponía la vida privada-, que a su vez era inseparable de la afirmación de sí, la separación de las existencias y de los cuerpos. Ahora bien, por numerosas razones, la medicina contemporánea tiende a renunciar o a derogar este deber, 
en la medida en que ella se desplaza de un régimen individualista absolutista hacia un régimen social, en el que la administración se infiltra cada vez más en la relación antiguamente cerrada del médico-enfermo. Más exactamente: la medicina actual sigue apegada al principio de confidencialidad mientras que no cesa de zaherirlo; la revolución moral solo llega lentamente, incluso si es infaltable, porque la antigua deontología terminaba por perjudicar a la propia medicina.

Tomemos un ejemplo. El ginecólogo obstetra no podía sino atestiguar el hecho de un nacimiento, pero no comunicaba ni el nombre de los padres, ni siquiera el lugar del parto. El legislador acaba de modificar la situación, pues la mayor parte desean que se pueda eventualmente, en ciertas ocasiones, revelar a un demandante las circunstancias y, sobre todo, los actores de su propio nacimiento.

Otro desgarrón: el deceso debidamente constatado entraña la redacción y la firma de una ficha destinada a los servicios de estadística; en ella se indicará en una tapa la causa de la muerte, pero en otra (aparte de la anterior) los apellidos y nombres del que se podrá inhumar. Las dos informaciones están disociadas, pero ¿cómo no relacionarlas? iPor todas partes el secreto se divulga! Cuando el médico declara una enfermedad contagiosa, utiliza una criptografía (números convenidos para tal o cual afección contagiosa) que es conocida de todos. Si se trata de enfermedades sexualmente transmisibles (ETS) como la sífilis, el médico deberá incluso señalar con nombre propio a los que se rehusaren a tratarse. De repente, la sociedad se pone a defenderse; la moral cambia cuando se teme la extensión del mal. Todavía existe un dominio donde el médico no deberá dudar: previene directamente a las autoridades con un señalamiento en caso de maltrato infantil. Si no lo hiciere -bajo el pretexto de respetar el principio de confidencialidad- estaría pactando con la extensión de la miseria.

Sobre esta cuestión, las excepciones no han dejado de multiplicarse. Es difícil aceptar que un médico que ha cuidado a una persona hasta su último suspiro, y que se informa de que un inocente es acusado de haberlo envenenado sea privado de la posibilidad de testimoniar. Teóricamente, él corre el riesgo, sin embargo, de hacerse merecedor a pesadas sanciones si habla.

El consejo de la orden ha evolucionado, sin embargo. Todavía ayer, no permitía la comunicación de la menor información sobre la patología y la terapéutica a los no-médicos, a los que no pertenecieran al cuerpo hospitalario. Si el secreto puede ser compartido entre médicos debidamente registrados no podrá serlo, sin embargo, con investigadores que no pertenezcan al cuerpo médico. Sin embargo, la Ley del $1^{\circ}$ de julio de 1994 acaba de flexibilizar las disposiciones de no-acceso; el acceso a los datos queda autorizado para investigadores, en la 
medida en que sus trabajos contribuyan a la mejora de la prestación del servicio. La CNIL (Comisión Nacional de Informática y de las Libertades) ha insistido para que los especialistas en biología puedan beneficiarse -y solo ellos- de la consulta de las bases de datos.

En resumen, la obligación absoluta del secreto perdió su importancia. Y no se trata simplemente de una flexibilización. Una revolución asoma a través de estos modestos cambios. De aquí en adelante la sociedad se interpone entre el médico y el enfermo. La antigua tesis de un encuentro confidencial, o de un diálogo singular, se ha desmoronado en momentos en que, primero, la colectividad se encarga hoy de financiar los cuidados y tiende por consiguiente a querer controlarlos, y segundo, la administración de salud no ignora que todas las patologías no se pueden comprender por fuera del grupo donde se ha desarrollado (el medio, las causas favorables, etc.). Ella también busca conocer sus frecuencias, por tanto, su peligrosidad.

\section{El metacuerpo}

Para salir de la contradicción entre técnicas de vanguardia y un encuadramiento jurídico-moral caduco, yo he debido renunciar evidentemente al fundamento biológico que nos pliega al determinismo, le pone mayor énfasis al peso de los datos y le concede demasiado a la corporeidad. No ignoro la importancia de lo orgánico, pero lo someto a exigencias más amplias.

Por lo demás ¿cómo podríamos continuar apoyándonos en la naturaleza cuando esta no cesa de ser cuestionada? ¿Cómo mantener aquí lo que está descartado en otra parte? Seguramente, esta referencia no deja de tranquilizar, en razón de su lado inmóvil (el no-cambio, la constancia, lo invariable), aunque todos se aperciban de que no existe nada inmutable o que permanezca tal. La propia naturaleza exterior -la que encantó a los pintores y a los escritores- supone la sociedad rural que la ha esculpido, y que por lo demás continúa renovándola. Ella entra en la historia de la que depende.

He debido pues recurrir a otro principio fundador, eventualmente susceptible de justificar e incluso de favorecer las audacias de la medicina actual. Solo animo o legitimo lo que vivifica a una comunidad, desde la más reducida (como la célula familiar) hasta la más amplia (las asociaciones de la sociedad civil). El hombre solo es hombre entre y con los hombres. Recordemos la fórmula "un hombre solo siempre está mal acompañado". Llegaría aún -con otro criterio que refuerza el precedente- hasta acudir a un metacuerpo con el fin de expulsar definitivamente los residuos individualistas o la impermeabilidad de un corporal que se impone demasiado en tanto que tal, mientras que yo lo ligo al reconocimiento y a la vitalidad de los otros. 
De acuerdo con estos principios, he abogado -si ellos lo desean- que los pacsados ${ }^{6}$ tengan la posibilidad de procrear (la filiación). Sirvo así a su propio entendimiento. Incluso privilegio, como se debe, la siguiente maniobra: en el caso de una pareja de mujeres, el ovocito de la una puede ser fecundado in vitro por el esperma provisto por el Cecos. El embrión que de acá resulte será implantado en el útero de su compañera, de tal manera que las dos mujeres participen en el nacimiento del niño. La una habrá dado entonces lo que permite la reproducción, y la otra ha asegurado el embarazo tanto como el parto. Las dos pacsadas han reforzado su lazo, y quedan así más unidas al niño que acaba de nacer. Consolido pues, y me alegro por esta comunidad de base.

Estoy buscando que los cuerpos cuenten un poco menos. Es una de las razones que me obligan -como moralista- a reconocer la importancia de la pareja homosexual que la naturaleza descarta, y que sin duda condena. Me felicito aún cuando un cuerpo logra incrustarse en otro para revigorizarlo como en el caso del implante, aunque falte el asentimiento de aquel al que se le extrae el órgano vital. La naturaleza individual y restrictiva, por definición no-dócil, se opone a esta compenetración curativa, y el cirujano (plástico) debe respetar las obligaciones reglamentarias. No puede ir más allá de las decisiones de los unos y de los otros. Censuro esos residuos de normas de ayer, y prefiero reclamar para ello un metacuerpo, es decir, que los casi-difuntos (que están en coma depassé) ayudaran a la resurrección de los inválidos, una solidaridad bioespiritual, radiante y auxiliadora.

La solución preconizada exige, sin embargo, ser matizada: primero, nadie duda de que una "oferta" consentida (cuando el sujeto se encontraba en buena salud, y por tanto lúcido) es, de lejos, mucho más valiosa que una extracción de oficio. Pero, en caso de penuria ¿conviene mantener esta situación a la espera del órgano salvador que entonces sería propuesto?

Un condenado de allende el Atlántico solicitaba que se retirara del condenado a muerte, inmediatamente después de su ejecución, las vísceras deseadas (el corazón, el hígado, etc.). Me opongo a este cínico aprovisionamiento; no quiero deberle nada, ni siquiera recibir nada de un ejecutado, puesto que repruebo la sanción que lo ha golpeado. iQue nadie acepte las recaídas de un asesinato! El cuerpo del hombre, en esta circunstancia, ha sido transformado en un vil medio, el de proveer a los centros hospitalarios. iCómo estamos entonces de lejos de la imbricación salvadora, compasiva y solidaria que he llamado el metacuerpo!

El pacs, pacto civil de solidaridad, es esencialmente contractual y está destinado a crear solo una pareja, no una familia. 
Importa, sin embargo, desdramatizar la extracción deseada. Si los poderes públicos obligasen a todos a donar sangre, porque faltan para las transfusiones que se necesitan, nadie protestaría. Aquí, los cuerpos se intercambian y se sostienen mutuamente sin verdadero problema. La facilidad de esta transferencia tiene que ver con que la sangre se reproduce, se reconstituye pronto, mientras que las vísceras -como el corazón que está colocado en el centro de la vitalidad- no se regeneran.

En suma, si uno -o sus representantes, si se es un menor- se opone a la donación (aunque no pierda nada en esa cesión), es porque se sigue apegado a la separación, y se rechaza el intercambio. Pero, por supuesto, yo solo mantengo esta especie de nacionalización de los cuerpos con fines estrictamente terapéuticos.

Una nueva deontología se impone pues, tanto más cuanto que la tradicional se pone a naufragar por todas partes, con una responsabilidad que se extiende y un secreto que se divulga. Estos dos pilares del orden antiguo han cedido. Conviene de ahora en adelante construir una teoría moral operativa que sirva a la biomedicina actual. 